\title{
Antenatal Detection of Fetal Syndromes by Ultrasound: From a Single Piece to a Complete Puzzle
}

\author{
${ }^{1}$ Lara Spalldi Barisic, ${ }^{2}$ Asim Kurjak, ${ }^{3}$ Ritsuko K Pooh, ${ }^{4}$ Taib Delic, ${ }^{5}$ Milan Stanojevic, ${ }^{6}$ Selma Porovic
}

\begin{abstract}
There are hundreds of known fetal syndromes and their variant yet, the real occurrence for most of them is not quite known, only estimated. The real incidence is probably much higher, but many of them are lost due to natural selection early, in the first few weeks of existence. Novel technology, enables us also to exchange information and improve the team's cumulative knowledge. Detection of dysmorphic features and recognizable patterns of fetal malformations and diagnosing syndromes is still big challenge in prenatal as well as postnatal period.
\end{abstract}

Keywords: Dysmorphic features, Fetal sonographic assessment, Fetal syndromes, Medical ethics, Online databases, Prenatal, Recognizable patterns, Three-/four-dimensional ultrasound.

How to cite this article: Barisic LS, KurjakA, Pooh RK, Delic T, Stanojevic M, Porovic S. Antenatal Detection of Fetal Syndromes by Ultrasound: From a Single Piece to a Complete Puzzle. Donald School J Ultrasound Obstet Gynecol 2016;10(1):63-77.

\section{Source of support: Nil}

Conflict of interest: None

\section{INTRODUCTION}

To be able to recognize abnormal, we have to be trained to recognize normal fetal appearance on ultrasound imaging and to distinguish one from the other. Knowledge of basic embryology (sonoembryology) and normal appearance of fetal anatomy in given gestational age is essential for understanding the relationship between normal and abnormal embryologic development

\footnotetext{
${ }^{1}$ Specialist and Director, ${ }^{2}$ Professor and President (Emeritus)

${ }^{3}$ President, ${ }^{4}$ Director, ${ }^{5} \mathrm{Head}$ of Neonatology and President

${ }^{6}$ Specialist

${ }^{1}$ Croatian Branch of Ian Donald Inter-University School of Medical Ultrasound, Zagreb, Croatia

${ }^{2}$ International Academy of Perinatal Medicine, Zagreb, Croatia

${ }^{3}$ CRIFM Clinical Research Institute of Fetal Medicine, Pooh Maternity Clinic, Osaka, Japan

${ }^{4}$ Polyclinic Sunce, Sarajevo, Bosnia and Herzegovina

${ }^{5}$ Department of Obstetrics and Gynecology, Medical School University of Zagreb, Sveti Duh Clinical Hospital; World Academy of Perinatal Medicine, Zagreb, Croatia

${ }^{6}$ Department of Pediatric Dentistry, Public Health Center of the Sarajevo Canton, Sarajevo, Bosnia and Herzegovina
}

Corresponding Author: Lara Spalldi Barisic, Specialist and Director, Croatian Branch of lan Donald Inter-University School of Medical Ultrasound, Zagreb, Croatia, e-mail: spalldi@gmail.com and dysmorphology. ${ }^{54-56}$ For sonographer this means training and practicing hands on, preferably with more experienced sonographer, which would be willing to share tips and tricks of scanning. As the technology and sonographers skills improve, higher the detection rate of fetal syndromes will be. Continuous education is very important to keep up with emerging new technologies, new diagnostic tools, especially in the field of ultrasound, so, this would be part of progress and not limitation. Common terminology used to describe fetal syndromes, sometimes may be confusing as wide variety of terms and definitions are used to describe it.

\section{Defining a Fetal Syndrome}

So, what exactly is a syndrome?

The term syndrome is derived from the ancient Greek word syndrome meaning running together. ${ }^{1}$ Syndrome is the association of signs, symptoms, dysmorphic features, and/or behaviors which occur together in a specific pattern in the same individual. Syndrome is made of particular combination of major criteria, which are fundamental to the diagnosis and minor criteria, that are just occasionally present (may be absent). ${ }^{2}$ Furthermore, it is important to make a distinction between a syndrome, a sequence and an association.

In syndromes, typically, anomalies, multiple malformations and/or sequences occur together in the recognizable pattern and they are result of a single (often genetic) abnormality (as in trisomy $18=$ Edwards syndrome).

A sequence occurs when a single developmental defect results in a cascade of secondary defects, which may lead to tertiary defect and so on (Pierre-Robin sequence: mandibular hypoplasia, glossoptosis and cleft palate $=$ Robin sequence) ${ }^{3}$ Sequence may be isolated or associated to unrelated defects or part of a known syndrome. It may also have multiple known causes. [Pierre Robin sequence (PRS) may have numerous (mostly still unknown) causes, such as recently identified genetic anomalies at chromosomes 2,11 , or 17]. ${ }^{3,4}$

Associations are nonrandom combination of birth defects, which may have resulted from a number of genetic factors $($ VATER association $=$ vertebral anomalies, imperforate anus, and esophageal atresia with tracheoesophageal fistula). ${ }^{1,4}$ Clinical dysmorphology is 
the study of abnormal human development with specific accent on rare syndromes causing malformations or alterations in body form. ${ }^{2}$ If there is one unusual feature (suspicion something is different from what we are use to see as normal) we should look further as there could be more. We also have to have in mind the possibility of numerous variations of normal, which sometimes can be recognized in parents too. There are few pathophysiologic mechanisms for fetal maldevelopment.

Malformation is commonly defined as a single localized poor formation of tissue that initiates a chain of subsequent defects (anencephaly). The recurrence risk for malformations generally range from 1 to $5 \%$. Deformation is a result of extrinsic mechanical forces on otherwise normal tissue (abnormal faces, pulmonary hypoplasia, and limb contractures that result from prolonged oligohydramnios due to oligohydramnios or primary renal agenesis in Potter syndrome). Disruption results from an extrinsic insult, which destroys normal tissue altering the formation of a structure (Amniotic band syndrome). Dysplasia results if the primary defect is a lack of normal organization of cells into tissue (achondroplasia). ${ }^{4}$

\section{Where to Find the Information?}

Identifying one anomaly, raises suspicion in existence of more which could be part of a bigger picture as being a syndrome. The trigger to look for this could be known family history or earlier pregnancy with malformed fetus/infant, history of consanguinity, exposure to teratogenic drugs or other agent, trauma or just detecting abnormality by regular US scan.

It is almost impossible to memorize characteristics of all of the fetal syndromes. However, we do have tools to help us and we know which of those syndromes occur more often than the other. They all have specific patterns. Some can be seen by prenatal sonographic examination, diagnosed and confirmed antenataly or direct postnataly, and some do not. Some syndromes are so rare and complex that the definitive diagnosis would be given many years later.

In the last few decades there has been some major breakthrough in the medical research field assisted by impressive evolution of new technologies. Identifying and mapping all of the genes of the human genome is unquestionably one of them..$^{5-7}$ A great advances has been made also in the field of noninvasive prenatal testing for early detection of fetal aneuploidy by commercially available tests using cell-free fetal DNA from maternal blood. ${ }^{8}$
The recognition of a set of anomalies as a potential syndrome, nowadays can be also aided by online available databases, such as London Dysmorphology Database (LDDB) or Online Mendelian Inheritance in Man (OMIM) where, among other things, there is a genetic disorder catalog, with all the known syndromes and their features. Search and review genetic resources including POSSUM web, Orphanet and GeneReview. Each every of these help us in finding, diagnosing and better understanding syndromes in their specific way.

There is no doubt, ultrasound with all of its possibilities $(2 \mathrm{D}, 3 \mathrm{D}, 4 \mathrm{D}$, etc.) is one of the best noninvasive, powerful visualization tools we have available for prenatal detection of fetal anomalies and syndromes. ${ }^{85,86}$ HDlive Flow and HDlive Silhouette imaging (GE Voluson E10) are one of the latest innovation which brings a totally new perspective, as we will show in illustrations, in visualizing structures with exceptional quality and accuracy of imaging just by increasing silhouette mode (Figs 3 to 6). Recently published (Sept 2015) Donald School Atlas of Advanced Ultrasound in Obstetrics and Gynecology with over thousand full color images (including HDlive Silhouette and HDlive Flow technology) and expert comments, is a great synopsis of all up-to-date knowledge and technology available in ultrasound concerning fetomaternal medicine. ${ }^{80}$

Evolution in ultrasound imaging technology allows us to assess not only the fetal anatomy to the smallest details, especially the fetal face, ${ }^{85,86}$ but also to follow the fetal behavior and test the functionality of the specific organs and whole systems. Great example of combining those two in one test was done in Kurjak's antenatal neurodevelopment (KANET) test introduced by Kurjak et al in 2008. ${ }^{9}$ Kurjak's antenatal neurodevelopment test is functional test for fetal brain, allows a systematic assessment of fetal neurobehavior, general movement and three signs (neurological thumb, small head circumference and overlapping sutures) that are considered postnataly as a markers, and may separate normal and abnormal behavioral patterns, that could prenatally indicate fetal brain impairment. Kurjak's antenatal neurodevelopment test should be performed in the 3rd trimester of pregnancy, between 28 and 38 gestational weeks. After validation, ${ }^{11}$ and many multicenter studies in recent years, it is concluded that KANET test can be used in everyday clinical practice for the follow-up of fetuses at neurological risk with the strong recommendation for strict and reliable multidisciplinary postnatal followup till the corrected age of at least 3 years and longer whenever appropriate. This way, it is possible to make correlation of prenatal KANET scores with postnatal 
neurodevelopmental outcomes. ${ }^{11,15}$ Kurjak's antenatal neurodevelopment test is performed with $4 \mathrm{D}$ ultrasound by licensed ultrasonographer for KANET test. ${ }^{9-11}$

Very useful as a reference for a sonographer, prenatal diagnostician, to find out information about sonographic finding and differential diagnosis in fetal syndromes is B. Benacerraf's book of 'Ultrasound of fetal syndromes'. ${ }^{12}$ Fascinating combination of science, research and new technologies is all together implemented in new research program on the way called: 'Give a face to a syndrome'. ${ }^{13}$

The Facial Dysmorphology Novel Analysis (FDNA ${ }^{\circledR}$ ) is a new technology that facilitates detection of facial dysmorphic features and recognizable patterns of human malformations (postnatal/adult life) to present comprehensive and up-to-date neurogenetic references available online.

Fetal syndromes may be classified on different basis. Typically they are divided in groups of major system involvement, such as syndrome featuring primarily facial anomalies or primarily featuring brain anomalies, craniosynostosis, limb abnormalities, skeletal dysplasia's ones which have in common intrauterine growth restriction or overgrowth or primarily soft-tissue anomalies. ${ }^{14} \mathrm{We}$ will discuss few of them with typical sonographically recognizable patterns.

\section{First Trimester Sonographically Detectable Anomalies Potentially Recognizable as Syndrome or Sequence}

An optimized an systematical approach to the evaluation of the fetus is summarized in International Society of Ultrasound in Obstetrics and Gynecology (ISUOG) guidelines for the basic examination. ${ }^{16}$ More detailed evaluation of fetal central nervous system (CNS) is indicated for pregnancies at high risk for CNS abnormalities (present in many syndromes) and fetal neurosonogram ${ }^{16,17}$ as well as KANET test should be offered to those. ${ }^{15,17}$ Suspected heart anomalies will require more comprehensive evaluation using fetal echocardiography. ${ }^{83}$ The use of transvaginal high resolution ultrasound and 3D ultrasound added more accuracy in the fetal assessment and enabled early diagnosis of major fetal anomalies and syndromes. ${ }^{18,19}$

It is commonly accepted that the single most effective marker of Down syndrome (trisomy 21) and all other major aneuploidies is increased nuchal translucency (NT) at $11+$ 0 to $13+6$ weeks. In combination with other well known parameters in the first trimester screening (maternal age, nasal bone, Doppler assessment of blood flow in the ductus venosus and across the tricuspid valve together with maternal serum free $\beta$-hCG and PAPP-A) more than 95\% of all major aneuploidies can be identified. ${ }^{20}$

There are some other anomalies that are frequently seen in fetuses with increased NT $(>3.5 \mathrm{~mm})$, such as omphalocele, hernia diaphragmatica, body stalk anomaly and many syndromes and sequences, such as Noonan syndrome, Smith-Lemil Opitz, fetal akinesia deformation sequence, congenital adrenal hyperplasia and so on.

The intracranial translucency (IT) may be used as an ultrasonographic marker in the first trimester detection of open spina bifida. This is the space between the posterior margin of the brainstem and anterior margin of choroid plexus of fourth ventricle. The intracranial translucency may be absent in fetuses with open spinal canal defect. It is measured at the same period $(11+0-13+6$ weeks), in the same plane as that for NT and its parallel to NT (Fig. 1). In the second trimester, in most fetuses with open spina bifida, sonographically we may observe the squaring of the frontal bones (the 'lemon' sign) and caudal displacement and compression of the cerebellum with obliteration of cisterna magna (the 'banana'sign). These three signs, absent IT in 1st trimester and lemon and banana signs in 2nd trimester of pregnancy are the manifestations of (Arnold-) Chiari II malformation ${ }^{21-24}$ (Fig. 2). Chiari malformation (I-IV) can be also part of some other syndromes, such as Marfan and Ehlers-Danlos syndrome, Craniocervical hypermobility syndromes, Klippel-Feil anomaly.

Frontomaxillary facial (FMF) angle measurement can be helpful in early detection of the fetuses with facial dysmorphic features, such as midface hypoplasia, which is present in many fetal syndromes (Down syndrome, Edwards syndrome, Patau syndrome and many craniosynostosis syndromes). This is recognized as a shallow FMF angle. The measurement is done in the first trimester, same period as NT and IT $(11+0-13+6$ weeks) and the image requirements are the same to those of NT and IT. The use of 3D ultrasound can be helpful in

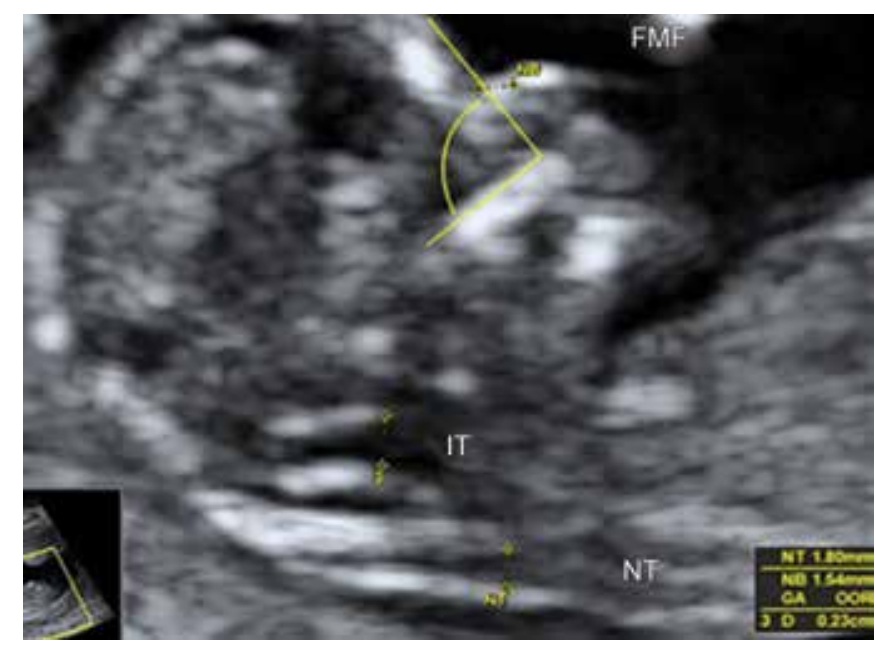

Fig. 1: Two-dimensional conventional image of a fetus in midsagittal view; assessment of NT, IT and FMF in normal fetus following the Fetal Medicine Foundation criteria 

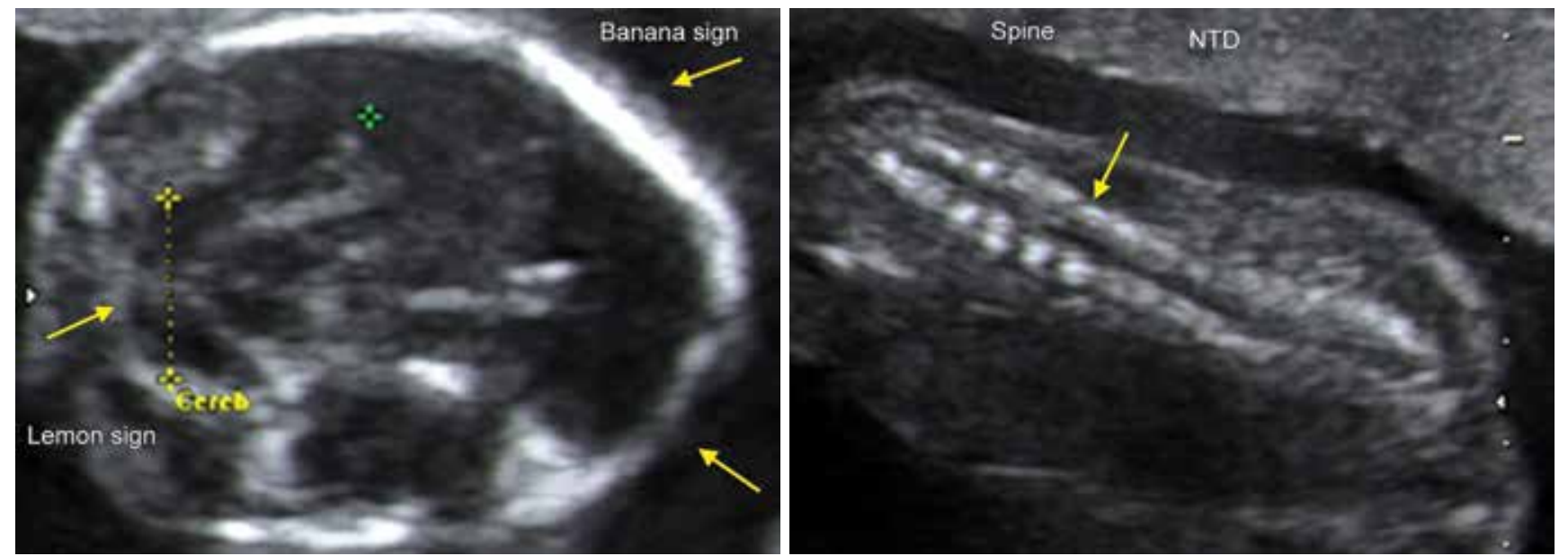

Fig. 2: Chiari type II malformation case with typical lemon and banana signs on the first image and NTD detected at 14 weeks of gestation on conventional 2D image
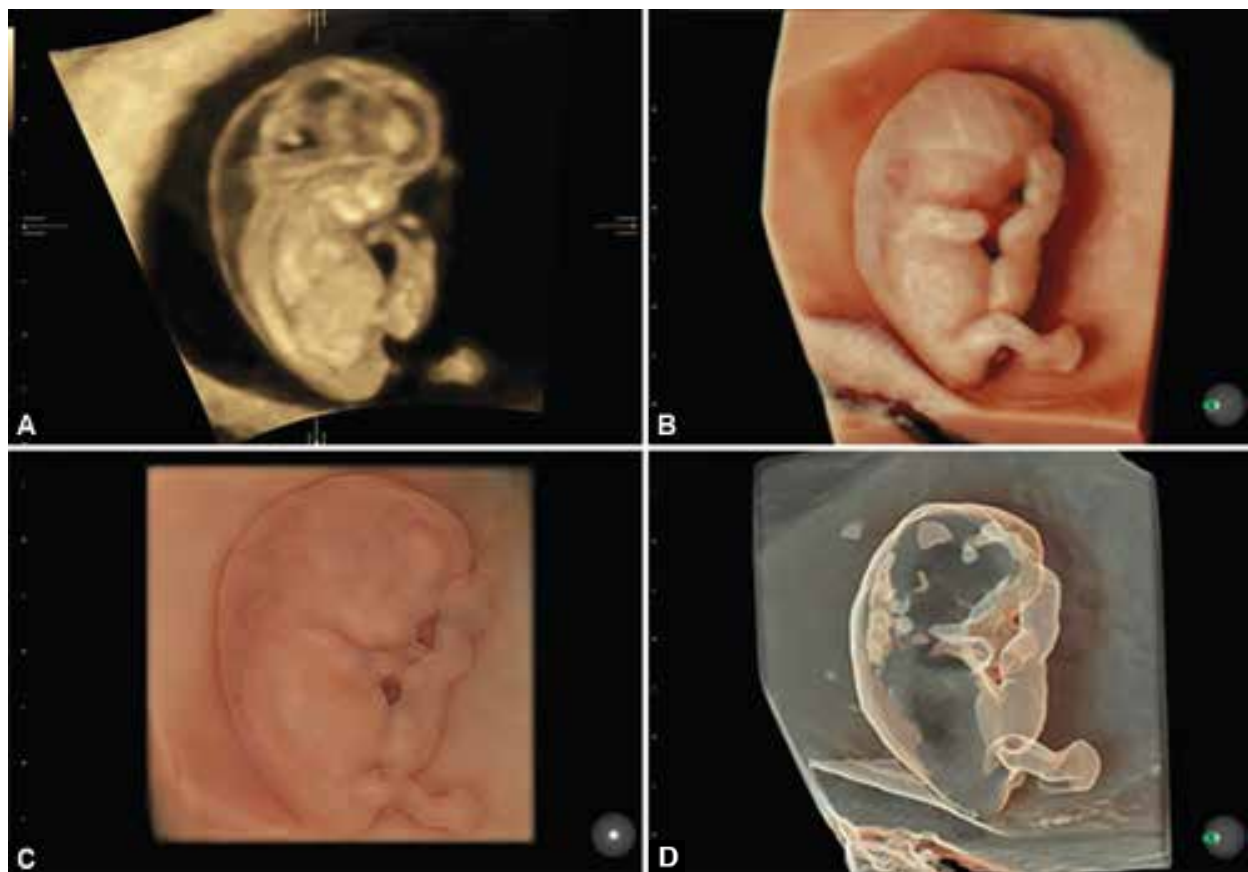

Figs 3A to D: Images of 9-week embryo with thick NT: (A) VCl sagittal image, increased NT is visible. (B-D) ${ }^{*}$ HDlive silhouette images. With increased silhouette mode, translucent fetus is visible. (Note: Images with the permission of the publisher ${ }^{80}$ ), ${ }^{*} \mathrm{D}$ : Noted the tiny cysts in the increased NT

establishing the precise midline section as in the NT and IT measurements..$^{25,26}$

\section{CLINICAL APPLICATION OF NEW US TECHNOLOGIES}

Euroscan group did a large study and collected data from 20 registries of congenital malformations in 12 European countries. They reported that about $50 \%$ of the recognized syndromes which are associated with major congenital anomalies (cardiac, renal, intestinal, limb defects, abdominal wall defects and oral clefts) can be detected prenatally by the anomaly scan. ${ }^{71,73}$ The detection rate varies with the type of syndrome and with the different countries policies of prenatal screening. ${ }^{66,76-78}$
Three-dimensional compared with 2D ultrasound was done by Merz et $\mathrm{al}^{30}$ and they examined large group of 3472 fetuses evaluated with detailed 2D and 3D US targeted for fetal anomalies. The total number of defects was 1012. Comparing the 2D and 3D technique, 3D US proved advantageous in $60.8 \%$ of the defects, which was related to the favorable demonstration of targeted areas in different views (e.g. multiplanar, surface). ${ }^{30,31}$ There is no doubt that $3 \mathrm{D}$ sonography can provide additional and more specific diagnostic information on high risk and normal fetuses. ${ }^{60}$

Prune-Belly syndrome (PBS) is a rare, congenital, obstructive, urologic alteration that is associated with megacystic bladder and visible deformity(distention) of 


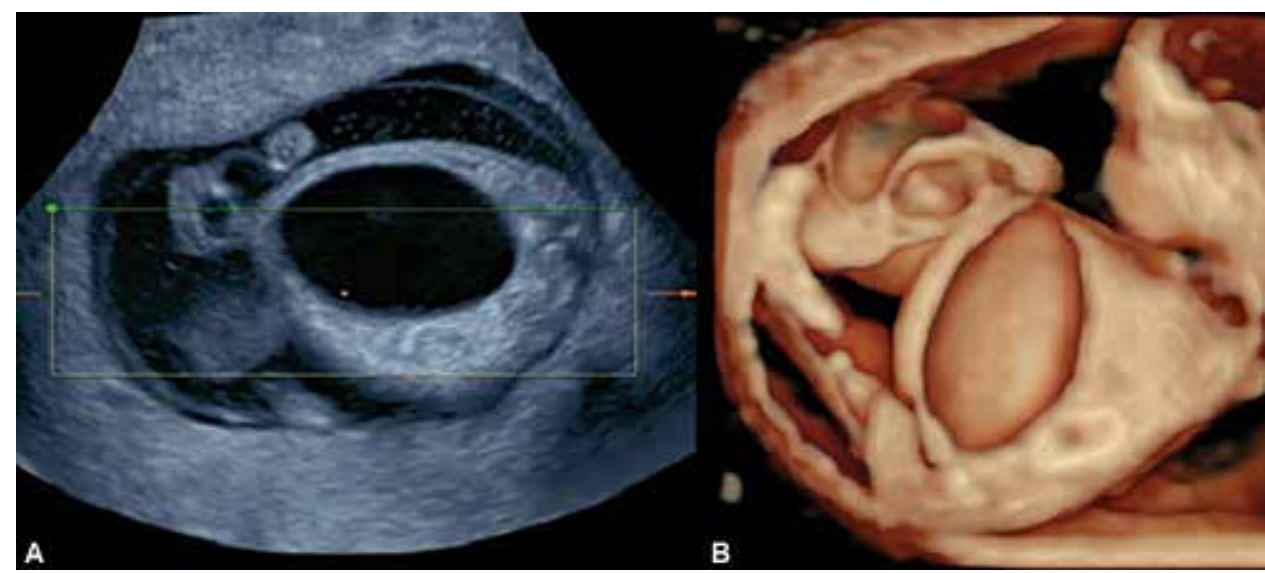

Figs 4A and $B:(A) 2 D$ image and $(B) 3 D$ reconstructed image

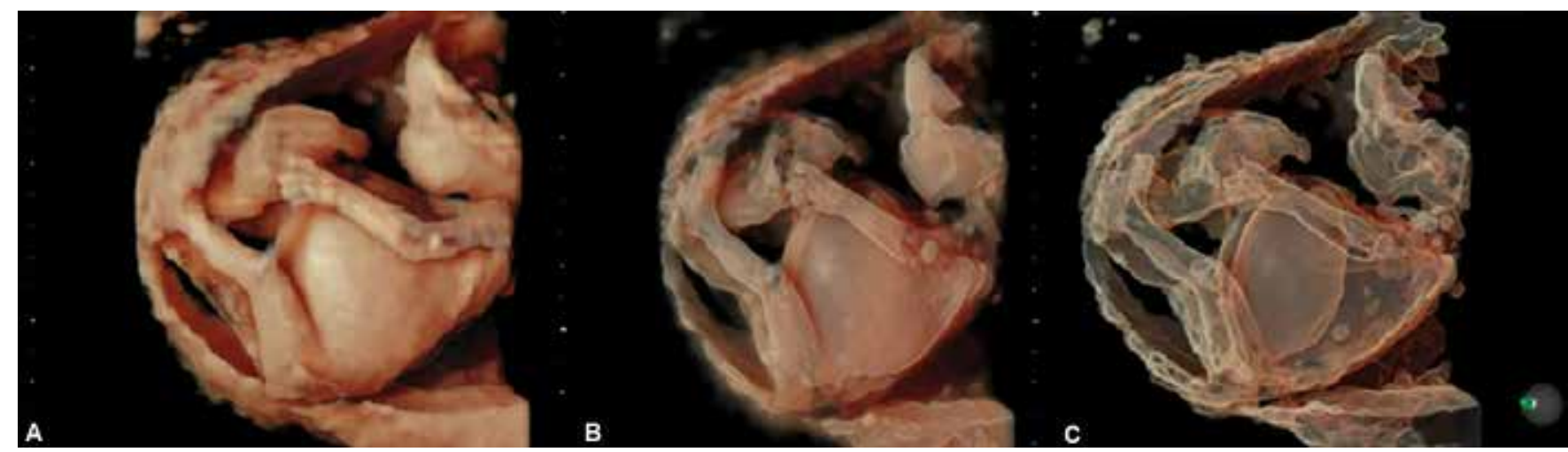

Figs 5A to C: (A) HDlive silhouette images with increased, (B) silhouette mode, translucent fetus, $(C)$ images with clearly visible distended bladder in Prune-Belly syndrome at 13 gestational weeks (Note: Images with the permission of the publisher ${ }^{80}$ )

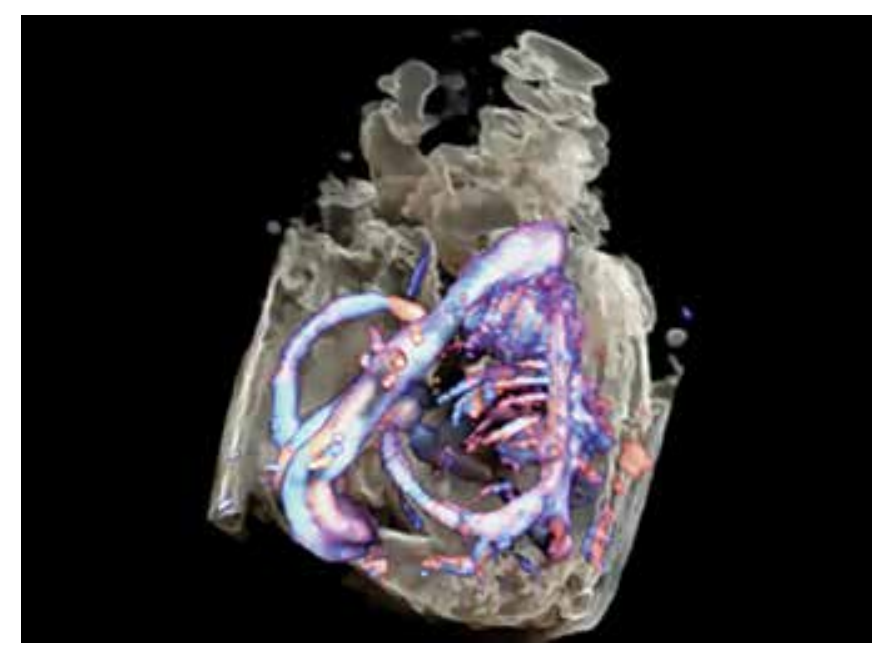

Fig. 6: Prune-Belly syndrome case at 13 gestational weeks, HDlive flow image of intracorporeal circulation (Note: Images with the permission of the publisher ${ }^{80}$ )

the abdominal wall (Figs 3 to 6). It is frequently associated with other fetal malformations. There is in addition renal hypoplasia (Fig. 7) or dysplasia and pulmonary hypoplasia. ${ }^{27}$

The incidence of PBS is estimated to be 1 in 30,000 to 50,000 newborn babies, but it is likely to be greater since many fetuses die in utero or are aborted. More than $97 \%$ of cases are male and only males develop the complete syndrome. The incidence is four times higher in twin gestations than in singleton pregnancies. ${ }^{27}$

\section{Syndromes Featuring Primarily Craniofacial Anomalies}

These syndromes may be divided in different groups, such as orofacial clefting, craniosynostosis, abnormal development of different branchial arches and simply dysmorphic faces. ${ }^{2}$ How do we decide what is normal and what is not if only discrete differences exist?

Although we all have the same basic features, we have our own distinguishing features and there is evidence that the brain (fusiform gyrus) has a specialized mental module dedicated to face processing. A researcher $G$ Yovel at TAU's Department of Psychology is working on understand how the mechanisms of the fusiform gyrus process information about how we recognize faces and interpret facial expressions.

Dysmorphic fetuses are diagnosed by meeting the criteria which are also used in the postnatal assessment, such as shape of the head and closure of the sutures, asymmetry of the face, hyper-hypotelorism, low set or abnormal ears, micro or retrognathia by measuring the Jaw-Index ${ }^{28}$ malformations, such as cleft lip and palate. ${ }^{43}$ 

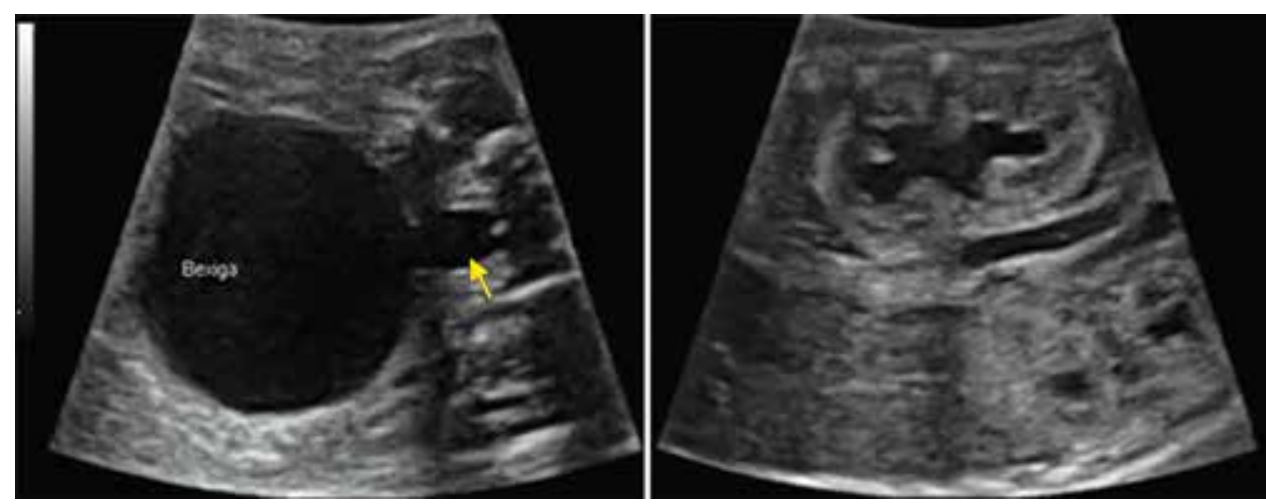

Fig. 7: Conventional 2D image of obstructed urinary tract with massive distention of bladder, megalourethra. The second image shows the same fetus with bilateral hydronephrosis and distended ureters in a case of Prune-Belly Syndrome (Courtesy. Dr RM Nieto)

Cleft lip/palate is one of the most frequent fetal anomalies. It can be an isolated finding (Fig. 8) (less than $50 \%$ of the fetuses) or combined with associated anomalies as part of a diverse syndromes. As an isolated defect it can be satisfyingly repaired with plastic surgery. Unfortunately, most fetuses with this anomaly have multiple severe abnormalities and high incidence of chromosomal anomalies. We can differentiate: bilateral complete cleft lip and palate which is easily identified even in 1st trimester, unilateral complete cleft lip and palate, incomplete cleft lip which has only subtle sign and can be easily overseen (Figs 9 to 11). Midline clefts are the most severe anomalies, regularly part of a severe sequence, such as holoprosencephaly and Patau (trisomy 13) and Edward's syndrome (trisomy 18), Aicardi syndrome. ${ }^{33}$ Trisomy 13 is the most common chromosomal abnormality associated with alobar holoprosencephaly (facial anomalies: cyclopia, cebocephaly, flat nose and cleft lip). However, a $75 \%$ of holoprosencephaly has normal karyotype. ${ }^{29}$

Mandibular anomalies are common in fetuses/ neonates, and micrognathia has been described in more than 100 syndromes. ${ }^{4,35}$

Micrognathia can be detected as an isolated structural anomaly, as one of the features of a chromosomal abnormality, or a syndrome. Teoh et al reported the prenatal diagnosis of severe micrognathia in a first trimester fetus with Pierre Robin sequence (PRS). ${ }^{36}$ For diagnosing micrognathia, Jaw-index can be helpful. It is defined by the ratio between AP diameter of mandible and $\mathrm{BPD}$. If the ratio is $<0.23$, diagnosis of micrognathia can be made. ${ }^{28}$

The PRS primary defect is hypoplastic mandible (occurs between the 7th and 11th week of gestation) which initiate chain of subsequent anomalies due to more posteriorly located tongue that disturbs the physiological closure of the posterior soft palate. The prevalence of PRS is approximately 1 per 8500 live births. As an isolated finding it has a very good prognosis with appropriate care

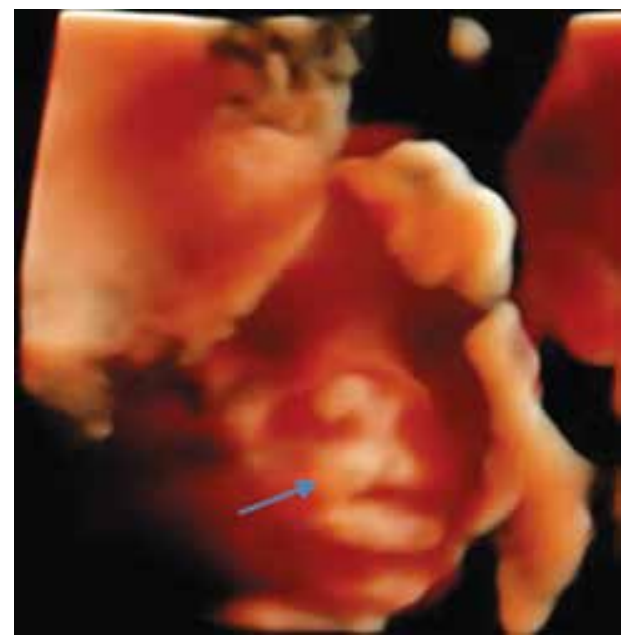

Fig. 8: Isolated cleft lip at $19 \mathrm{GW}$ detected with HDlive surface view (Note: Image with the permission of the publisher ${ }^{80}$ )

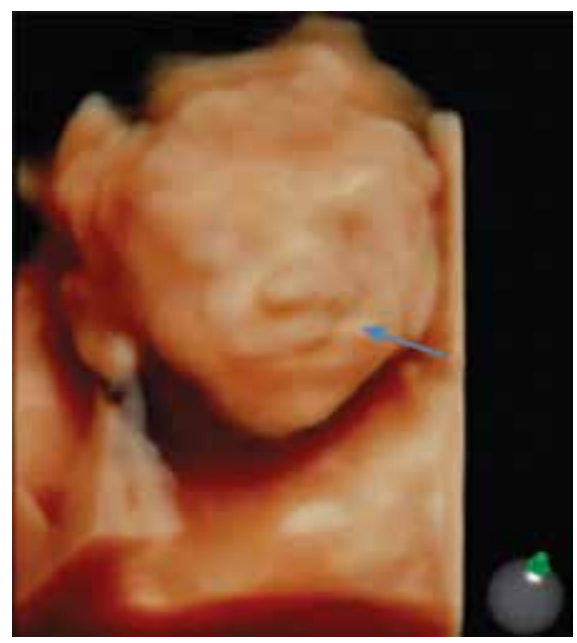

Fig. 9: HDlive image of the $21 \mathrm{GW}$ fetus with unilateral left sided cleft lip and palate

and management. ${ }^{12}$ The growth of the mandible catches up during the first year of life, however, mandibular hypoplasia resolves and the child attains a normal profile by approximately age of 5 to 6 years. ${ }^{37-39}$ As mentioned earlier, PRS can be feature of different syndromes, and the outcome will depend on the severity of the syndrome and its associated anomalies. ${ }^{12}$ 


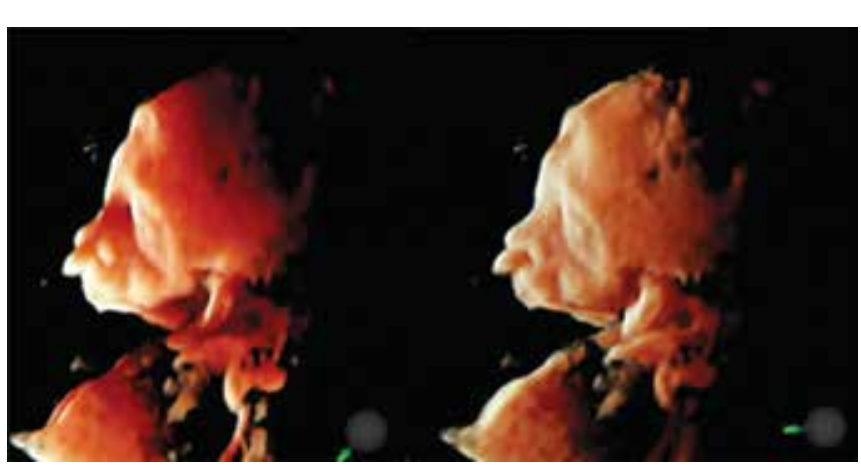

Fig. 10: HDlive surface view of the fetus with Patau syndrome (21 GW) with midline cleft (Note: Images with the permission of the publisher ${ }^{80}$ )

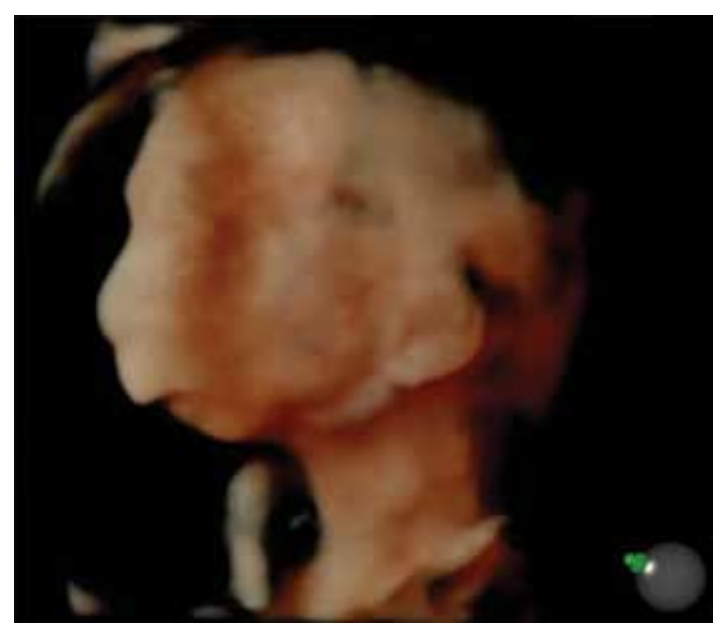

Fig. 11: HDlive surface view of fetus with micrognathia, 21 gestational weeks, Pierre Robin sequence as part of a syndrome (Courtesy: Dr Sonal)

More than 40 syndromes with PRS have been described, the most common of which are Stickler syndrome (SS) and 22q11.2 deletion syndrome (Di George syndrome or Shprintzen syndrome). Evans et al (2006) reviewed 115 patients with PRS. ${ }^{39}$ They have found that $54 \%(n=63)$ of patients were nonsyndromic. Syndromic patients included: Stickler syndrome $(18 \%)$, velocardiofacial syndrome $(7 \%)$, Treacher-Collins (5\%), facial and hemifacial microsomia $(3 \%)$, and other defined (3.5\%) and undefined $(9 \%)$ disorders. ${ }^{39}$

Detecting congenital micrognathia and low set ears together is not rare, on contrary, it is frequent finding especially in those cases with chromosomal aberrations and other syndromes. The connection/link between the two lies in the fact that they arises together from the first pharyngeal (branchial) arch. ${ }^{40}$ Tsai et al reported assessment of the facial features, chin development and mandibular size by 3D ultrasound in the second and third trimesters. ${ }^{41}$ A short maxillary length has been associated with trisomy $21 .^{42}$

Detecting an abnormal shape of the head may be feature of different syndromes (Fig. 13). The 'Strawberry' shaped head is typical finding in Edward's syndrome.
'Lemon' shaped head is caused by a neural tube defect and Chiari II malformation and several syndromes. 'Cloverleaf' head shape is mostly found in skeletal dysplasia's, such as Thanatophoric dysplasia (most common skeletal dysplasia with small faces, short, bowed long bones, narrow chest, short ribs) (Fig. 12) and some syndromes characterized by craniosynostosis, such as Crouzon and Pfeiffer syndrome. ${ }^{43}$

Craniosynostosis is caused by premature closure of fetal scull sutures and depending on which ones are involved, they result in different shapes of the head. By premature closure and fusion of coronal, sagittal and lambdoid sutures, acrocephaly (the top of the skull assumes a cone shape) is the result as seen in Crouzon syndrome (along with micrognathia, hyperhypotelorism, occasionally with agenesis of corpus callosum, cleft lip and palate). Synostosis of coronal and sagittal sutures results in brachycephaly as seen in Apert (high forehead, flat faces, hypertelorism, ACC, mild ventriculomegaly, syndactily of the $2 \mathrm{nd}$, 3rd and 4 th fingers $=$ 'mitten hand', cardiac defects and variable degrees of mental retardation); Carpenter (depressed nasal bridge, micrognathia and low set ears, cardiac

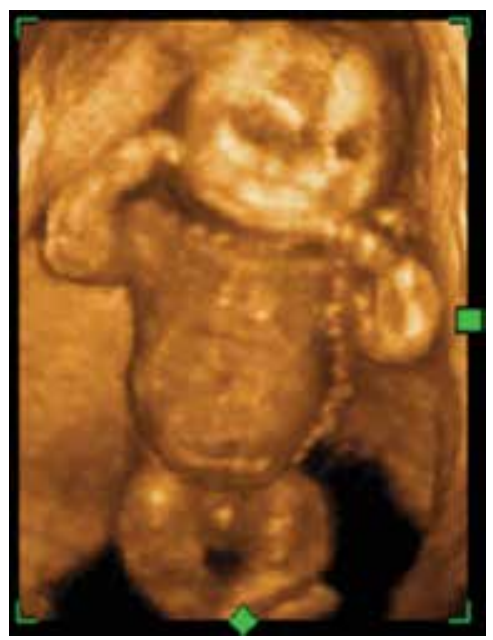

Fig. 12: Three-dimensional image of fetus with Thanatophoric dysplasia

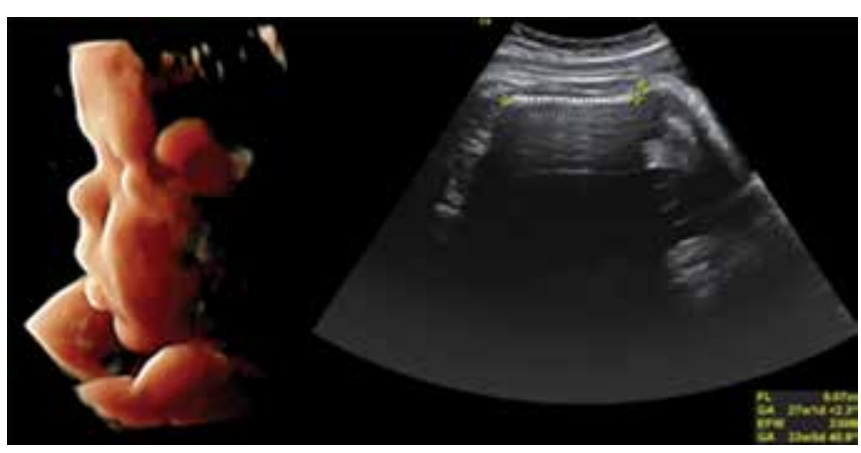

Fig. 13: HDlive surface view of fetal face, fetus suspected of Achondroplasia, notice frontal bossing and depressed nasal bridge; second image by conventional 2D, shows very short femur (length appropriate for $27 \mathrm{GW}$ ) at 34 weeks of gestation 


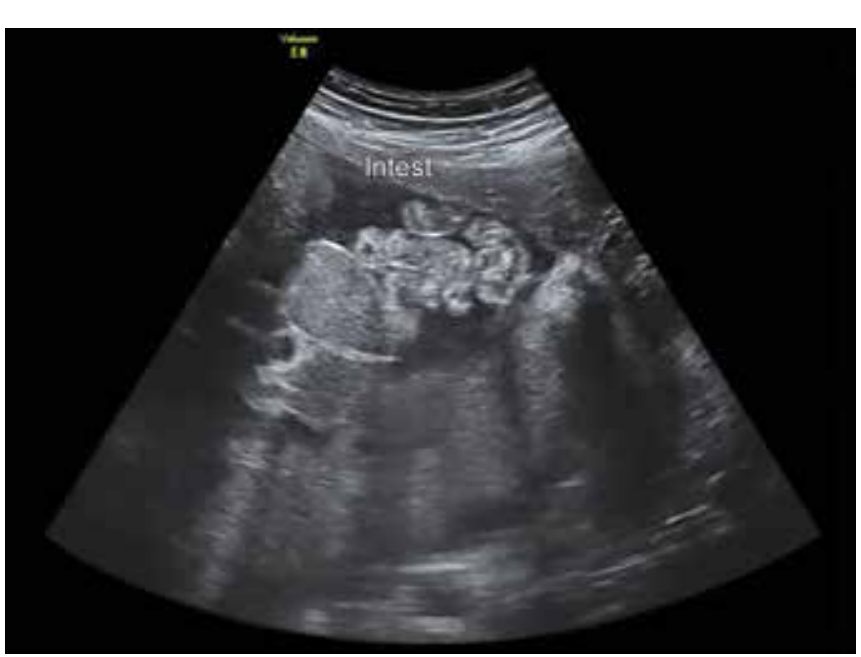

Fig. 14: Conventional 2D image of gastroschisis due to Amniotic Band Syndrome: fetal anterior abdominal wall defect with multiple bowel loops fluting free in the amniotic fluid (Courtesy. Dr RM Nieto)

defects, omphalocele, clinodactily, synpolydactyly) and Pfeiffer syndrome (sometimes cloverleaf skull, depressed nasal bridge, hypertelorism, broad hallux and thumb, occasional venticulomegaly and cardial defects). Syndromic craniosynostosis are all autosomal dominant conditions. They are differentiated by presence/absence of associated anomalies or by molecular analysis of fetal deoxyribonucleic acid (DNA). ${ }^{44}$

Frontal bossing may be seen in Russell-Silver syndrome (along with asymmetric IUGR of the skelet with normal size head, short stature) or Achondroplasia (Fig. 13) (rhizomelic limb shortening, autosomal dominant condition usually not apparent until late in 2nd trimester).
Skull asymmetry can be seen in Wolf-Hirschhorn syndrome (deletion $4 \mathrm{p}$ ) also called 'Greek warrior helmet' syndrome because of the appearance of the forehead. Incidence is estimated at 1 in 50,000 births. However, this may be underestimated because it is likely that some affected individuals are never diagnosed. It affects twice as many females as males. Typical face with hypertelorism, broad, flat nasal bridge continuing to the forehead, micrognathia and microcephaly along with ACC, cleft lip and palate, IUGR are some of the features that may be detectable by ultrasound.

Another syndrome which may cause skull asymmetry is Amniotic Band Syndrome (sequence) (Fig. 14) initiated by premature rupture of the amnion (most likely before 12 weeks of gestation), resulting in wide variety as well as severity of destructive processes depending on where the amniotic band comes into contact (facial clefting, encephalocele, asymetric anencephaly, micrognathia, gastroschisis, limbs defects and amputations and so on).

When a prenatal diagnosis of multicystic dysplastic kidney (MCDK) (Fig. 16) is made by ultrasound, the disease is found to be bilateral in many cases. Those with bilateral disease often have other severe deformities or multisystem malformation syndromes. In bilateral cases, there are typical features of Potter's syndrome ${ }^{45}$ (Figs 15 and 16). The incidence of MCDK is estimated to be 1 in every 4,000 live births, making it rare in terms of the general population. ${ }^{45,46}$

Meckel Gruber syndrome is lethal autosomal recessive condition, due to pulmonary hypoplasia and neonatal renal failure infants die within a first few days of their life.

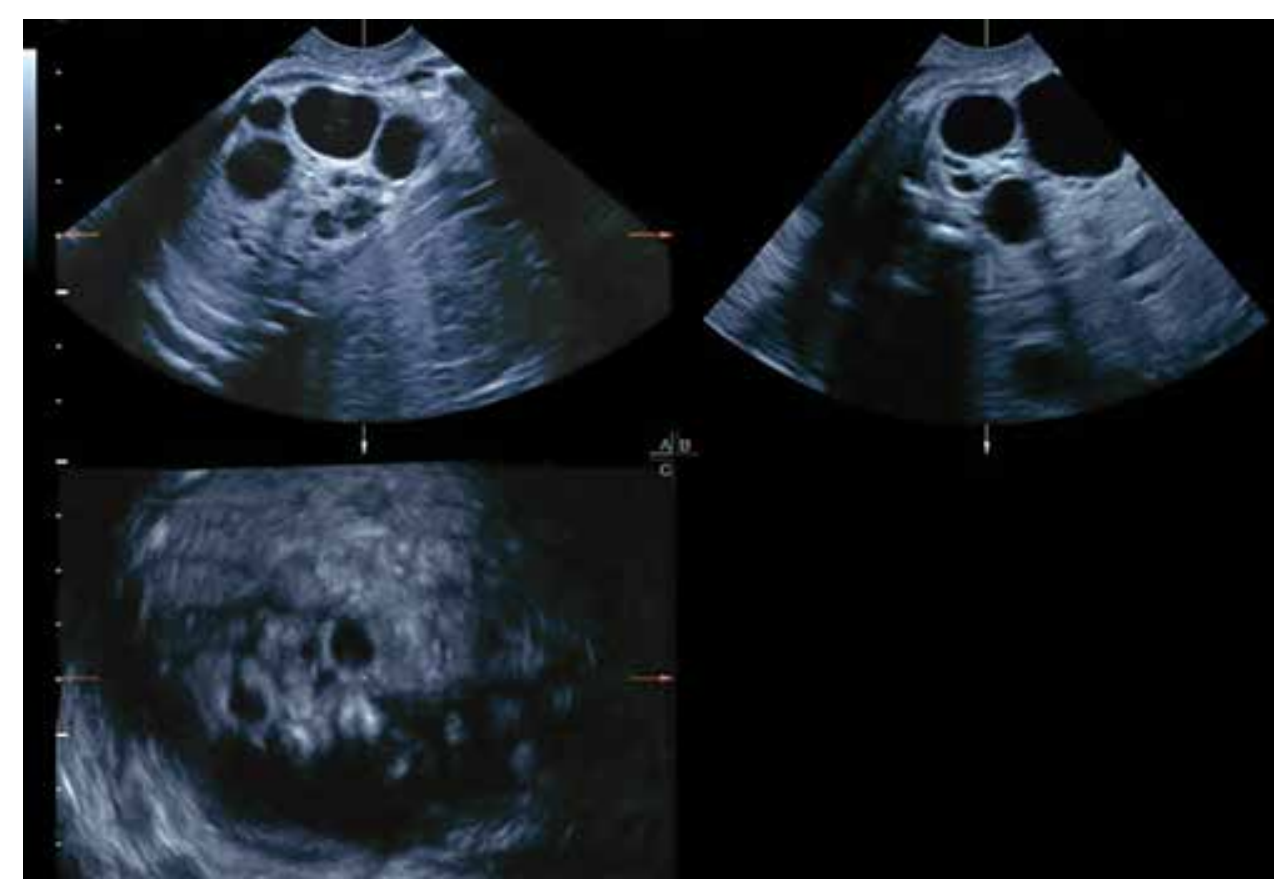

Fig. 15: Conventional 2D split image of fetus and MCDK = Multicystic Dysplastic Kidney, at 26 weeks of gestation, suspected of Potter syndrome 


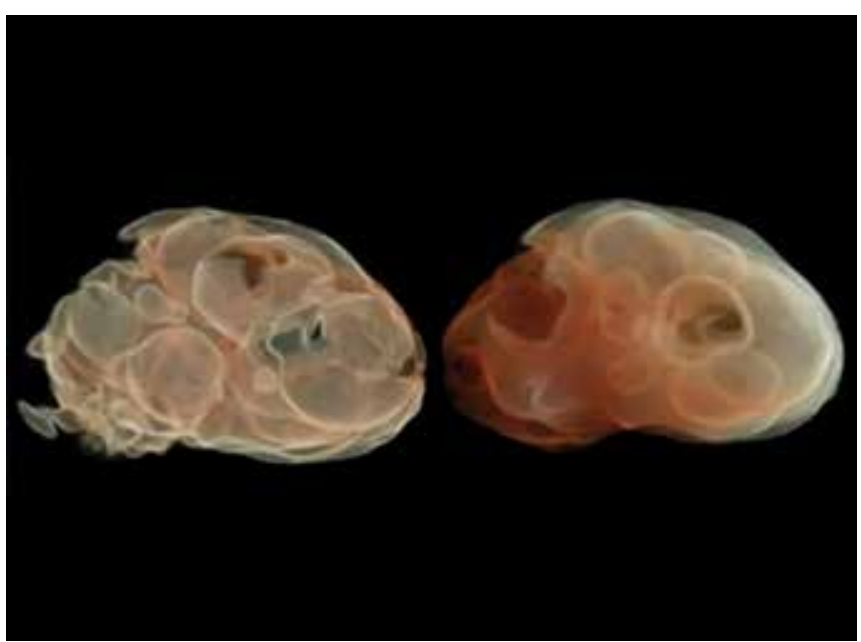

Fig. 16: Multicystic dysplastic kidney at 26 gestational weeks HDlive silhouette images volume extraction (GE, Voluson E10) (Note: Images with the permission of the publisher ${ }^{80}$ )

Typical trias of anomalies pathognomic of this syndromes are occipital encephalocele, cystic renal dysplasia (Fig. 17) and polydactyly. First trimester detection of occipital encephalocele has been often reported. Indeed, due to the normal amount of amniotic fluid early in pregnancy it is much easier to make diagnosis than later in the second trimester as oligohydramnios progresses and this anomalies can be overlooked. If encephalocele is diagnosed, fetal kidneys should be carefully examined. The normal sonographic findings of the kidneys rules the lethal Meckel Gruber syndrome out. ${ }^{48}$ For patients with suspicious findings on basic examination and/or increased risk of CNS abnormalities, fetal neurosonogram should be offered as well as KANET test in 3rd trimester. ${ }^{15,17}$

Dandy walker malformation (DWM) is posterior fossa abnormality (Figs 18 to 21) that occurs as a part of well known and recognizable syndromes: WalkerWarburg syndrome or Mechel's syndrome which both are associated with chromosomal aberrations. ${ }^{29}$

Blomley et $\mathrm{al}^{48}$ showed songraphcally that the closure of cerebellar vermis take place early in the second
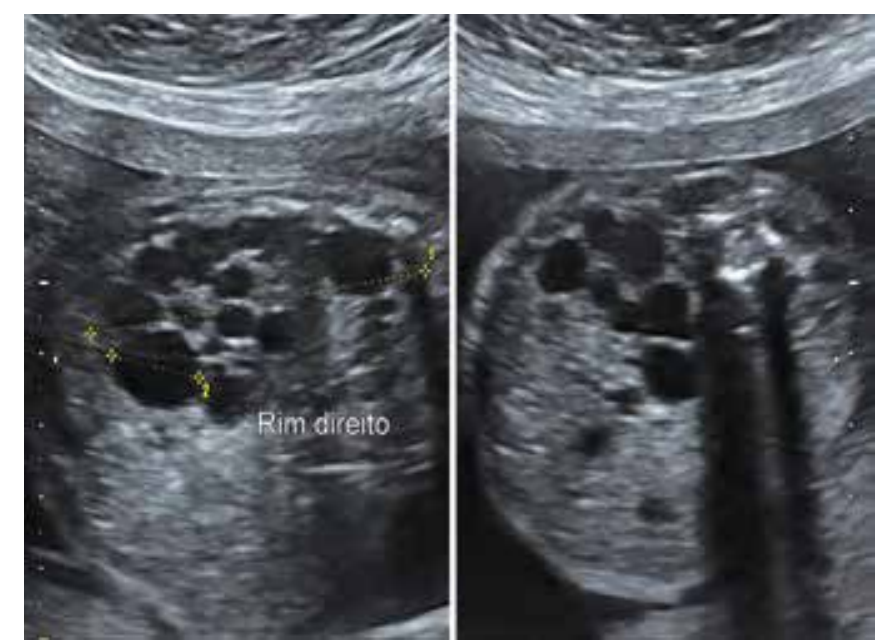

Fig. 17: Two-dimensional conventional split image of fetus with cystic dysplasia of the kidneys at $25 \mathrm{GW}$, found in fetus with Meckel Gruber syndrome. (Courtesy: Dr RM Nieto)

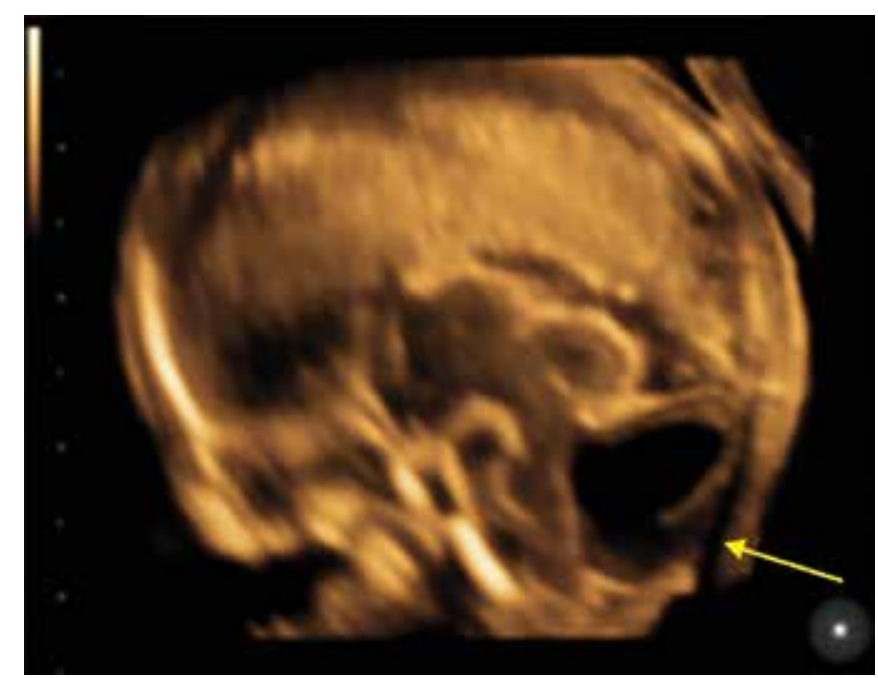

Fig. 18: HDlive image of DWM suspected at 16 weeks of gestation. Note the abnormal dilatation of posterior fossa (arrow)

trimester (14-18 GW). Even though diagnosis of Dandy Walker malformation should not be made before the 18 th week of gestation, sometimes suspicion can exist as early as from 11 weeks of gestation, trisomy 9 mosaicism was confirmed by amniocentesis in that particular case..$^{29}$

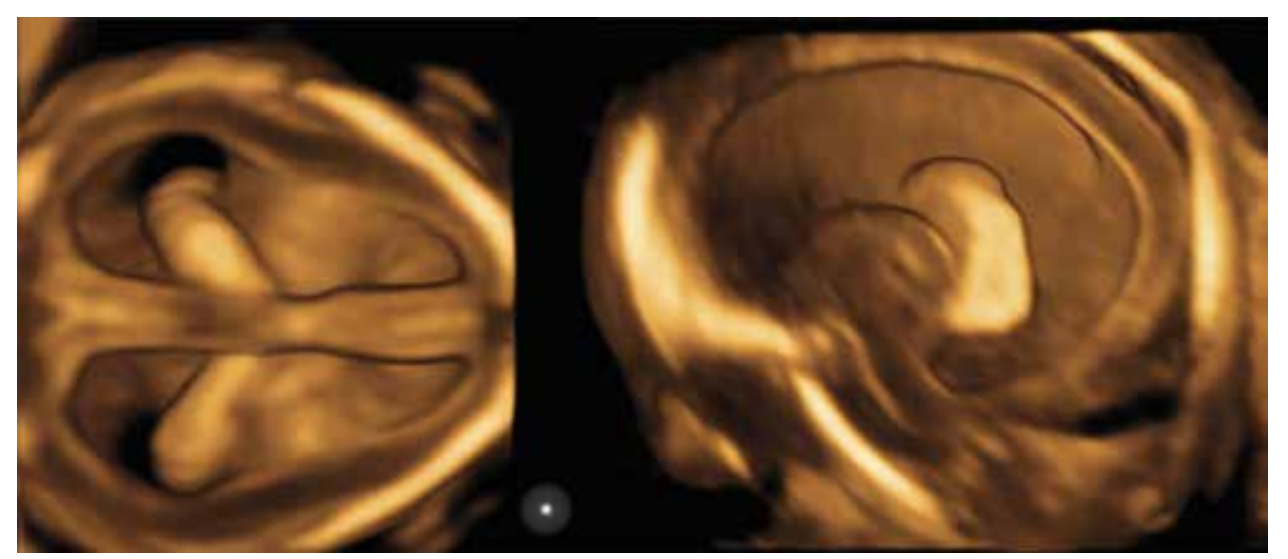

Fig. 19: HDlive image of DWM with ventriculomegaly and demonstration of well preserved choroid plexus 


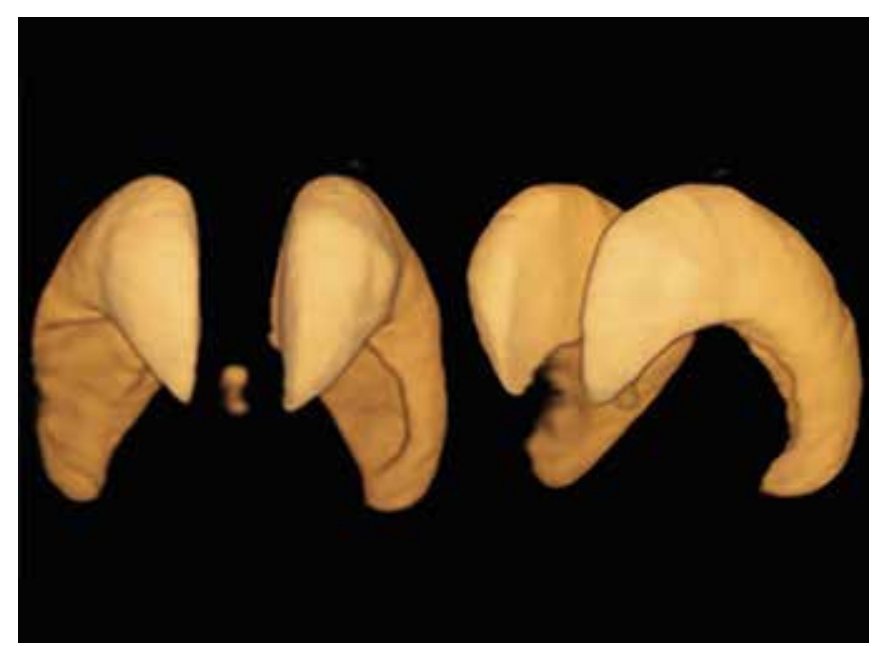

Fig. 20: Three-dimensional volume extraction of the lateral ventricles by inversion mode in ventriculomegaly case of DWM

\section{Syndromes Featuring Chromosomal Anomalies}

According to their etiology, syndromes can be divided in chromosomal or nonchromosomal. A chromosome anomaly, abnormality, aberration, or mutation (Fig. 22) is a missing, extra, or irregular portion of chromosomal DNA. A karyotype refers to a full set of chromosomes from an individual. Humans are diploid species: Two complete haploid sets, which make up 23 homologous chromosome pairs so, typical human somatic cell contains 46 chromosomes. There are many types of chromosome anomalies. Basically, they can be divided into two major groups: numerical and structural anomalies.

Numerical chromosomal abnormality can be aneuploidy or polyploidy.

Aneuploidy: An individual is missing either a chromosome from a pair (monosomy) or has more than two chromosomes of a pair (trisomy, tetrasomy, etc.).

Polyploidy: More than two sets of chromosomes per nucleus. Aneuploidy can be either autosomal = happens in autosomes (trisomy 21) (Figs 23 and 24) or sexual = happens in sex chromosomes (e.g. Turner syndrome monosomy X0). Trisomies can occur with any chromosome, but often result in miscarriage, rather than live birth. Trisomy 16 is the most common trisomy in human pregnancies, occurring in more than $1 \%$ of pregnancies; only those pregnancies in which some normal cells occur in addition to the trisomic cells (mosaic trisomy 16) survive. This condition, however, usually results in spontaneous miscarriage in the first trimester. ${ }^{49}$

Triploid syndrome (polyploidy) is an chromosomal disorder. A fetus with triploidy has three haploid sets of chromosomes, a total of 69 (instead of the normal 46 chromosomes). Only 1 in 10,000 infants is born with triploidy, and it is estimated that for every live-born infant with triploidy, 1,200 have been lost as miscarriages. There

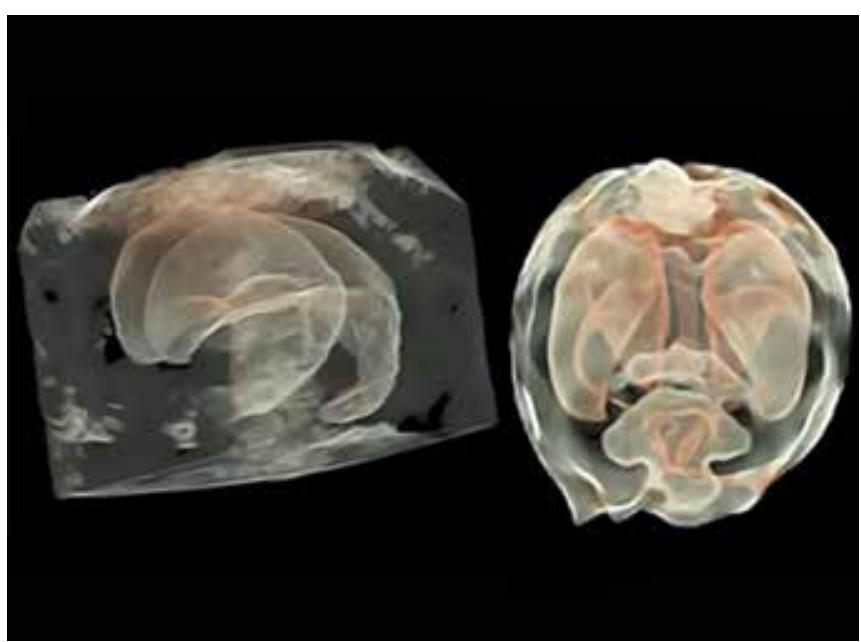

Fig. 21: HDlive silhouette (GE, Voluson E10) in DWM case demonstrating increased volume of 3 rd and 4 th ventricles in ventriculomegaly at $13 \mathrm{GW}$ (Note: Images 18 to 21 with the permission of the publisher ${ }^{80}$ )

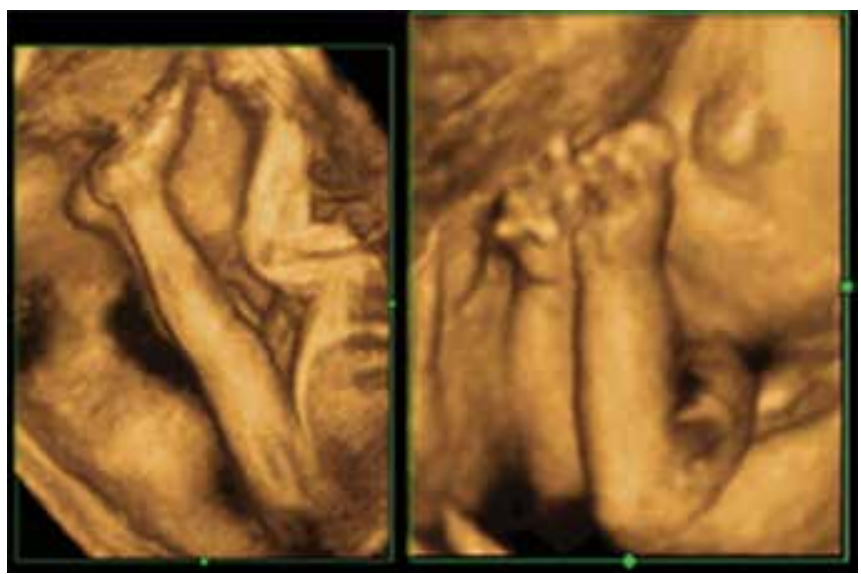

Fig. 22: Three-dimensional US image of fetus with Pena Shokeir syndrome or FADS, a Fetal Akinesia Deformation Sequence. Biallelic mutations in different genes have been identified in these patients (pseudo-trisomy 18), at 28 gestational weeks, with hyperextension contractures of the lover limbs and on the second image same fetus with arms in fixed flexed position with both clenched hands and camptodactyly. Dysmorphic face with micrognathia (Courtesy. Dr Sonal)

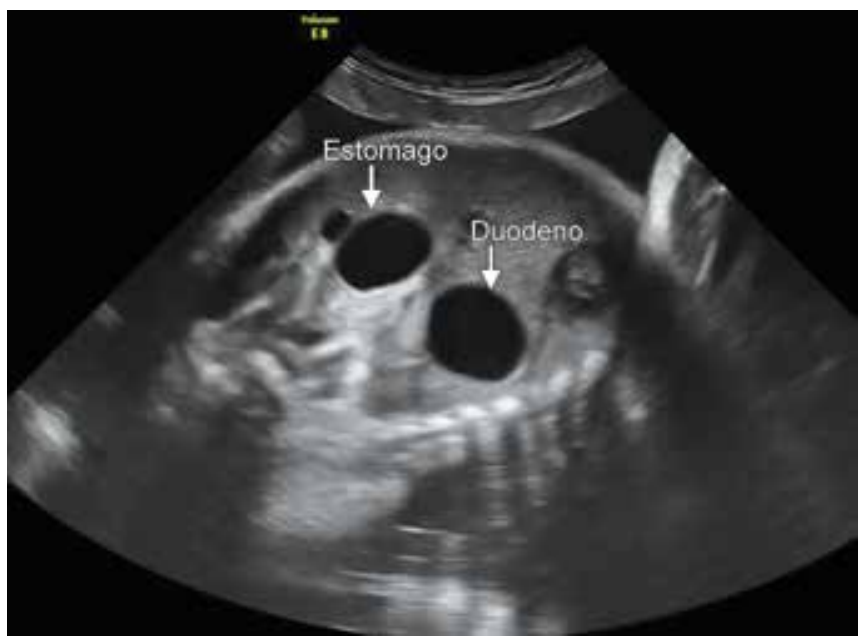

Fig. 23: Two-dimensional image of fetus with duodenal atresia 'Double Bubble sign' seen in Down syndrome (Courtesy: Dr RM Nieto) 


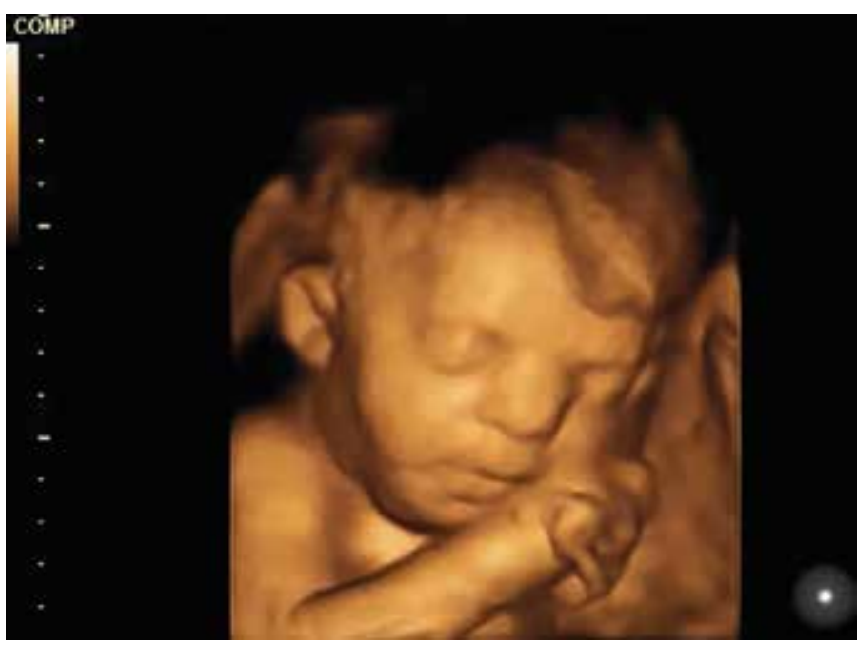

Fig. 24: Three-dimensional surface view of fetus (34 weeks gestation) with low set ears in Down syndrome (Courtesy: Dr Sonal)

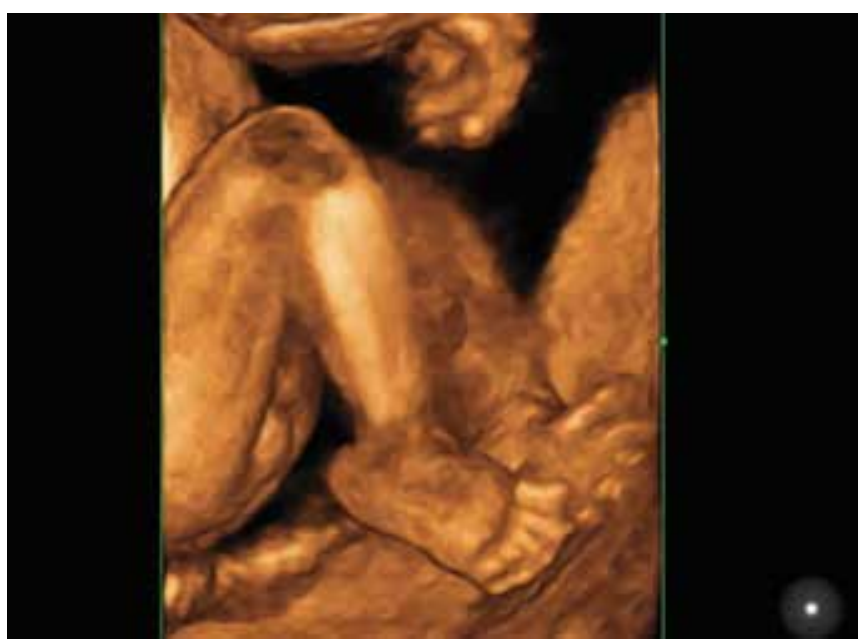

Fig. 26: Three-dimensional image of 17 weeks fetus with both clenched and club hands and feet diagnosed with Edward's syndrome (trisomy 18) (Courtesy: Dr Sonal)

are no risk factors. Couples who have one pregnancy with Triploidy do not have an increased risk in future pregnancies. Triploidy is not hereditary.

Fetuses with structural anomalies often have chromosomal anomaly too. Trisomies are present in $50 \%$ of the cases, monosomies in $25 \%$, mosaicism in 10 to $15 \%$ and in few percentages of the cases left, usually there is triploidy or miscellaneous aneuploidie. ${ }^{81,82}$

Nicolaides et $\mathrm{al}^{50}$ have found that fetuses with more than one anomaly are more likely to have chromosomal abnormality, respectively, with one anomaly risk is $2 \%$, with two anomalies $11 \%$, with five anomalies increasing to as high as $66 \%$ and with eight anomalies risk jumps to $92 \%$.

Edwards syndrome (Trisomy 18), very well-known syndrome, characterized by multiple organ system malformations. Incidence is 3:10 000 live births. First trimester most common finding is cystic hygroma and lymphangiectasia of fetal head, neck, scalp and so on. In early second trimester some of the detectable anomalies

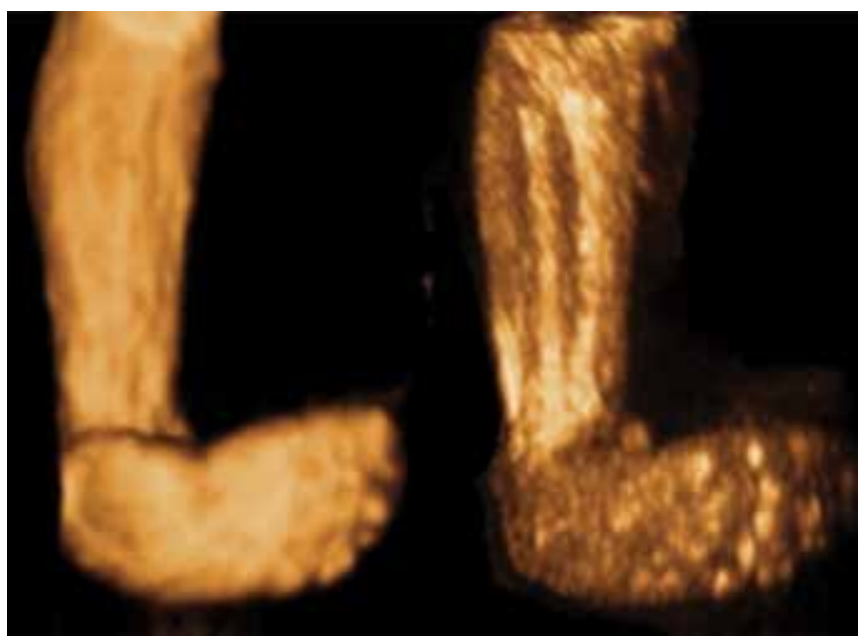

Fig. 25: Three-dimensional image of club foot in surface and maximum mode, fetus with diagnosed Edward's syndrome (Courtesy: Dr Sonal)

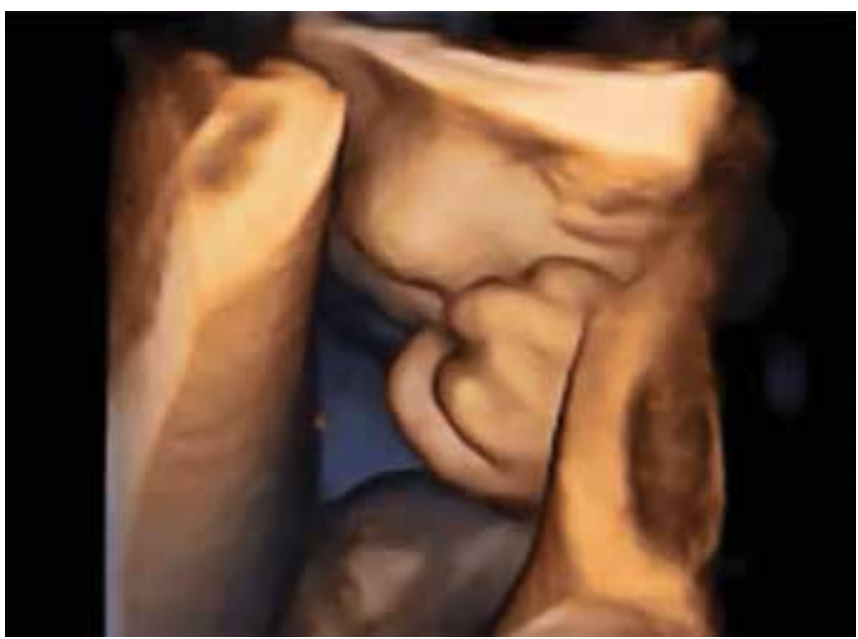

Fig. 27: HDlive image surface view of fetus with Edward's syndrome. Notice clenched hand and overlapping fingers (Courtesy. Dr Sonal)

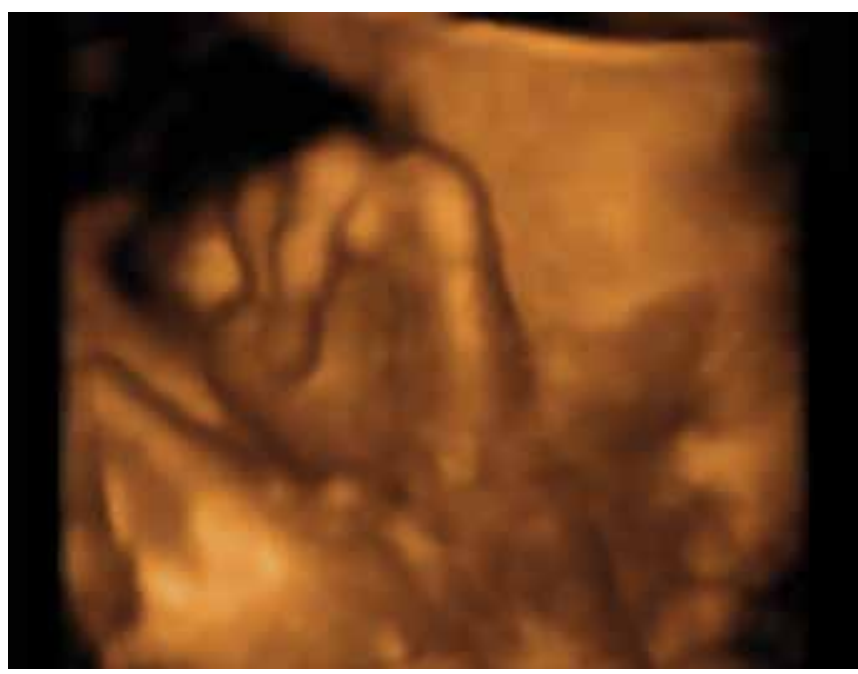

Fig. 28: Three-dimensional surface view image of fetus with clenched hand detail, Edward's syndrome (Courtesy: Dr Sonal)

include clenched hands (Figs 26 to 28), club feet, (Fig. 25) omphalocele, major cardiac defects, micrognathia and low set ears, choroid plexus cyst. ${ }^{43}$ 


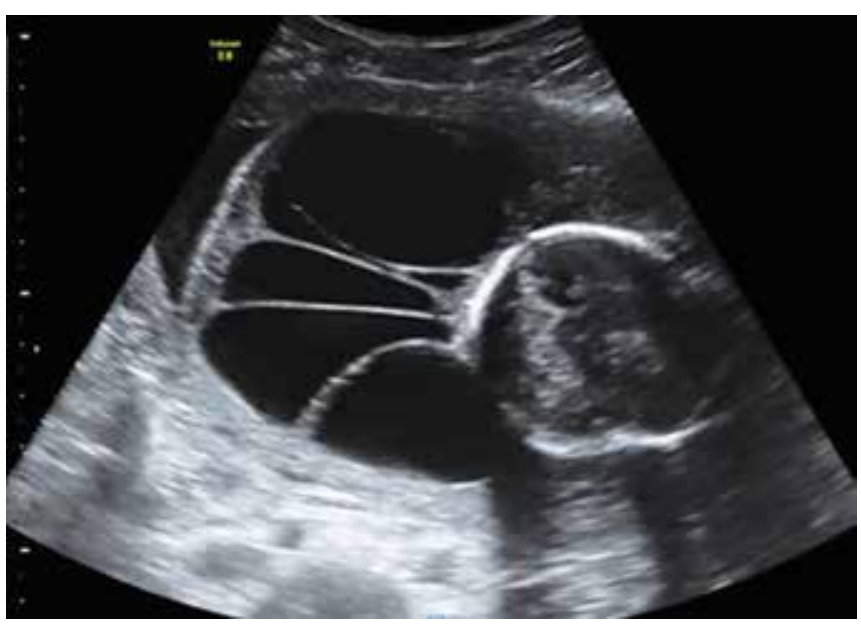

Fig. 29: Two-dimensional conventional image of the fetus with cystic hygroma colli, Turner syndrome (Monosomy X0) (Courtesy: Dr RM Nieto)

Choroid plexus cyst is seen in 30 to $50 \%$ of the fetuses with trisomy 18. Although trisomy 18 occurs in 1:100 fetuses with choroid plexus cyst, if it is an isolated finding, as Gross et $\mathrm{al}^{51}$ reported results from the metha-analysis, the risk of trisomy 18 falls on 1:374. Identifying an open hand while scanning can be very helpful finding, as most fetuses with Edward's syndrome are unable to unclench their hands. ${ }^{43,51}$

Cystic hygroma colli frequently has a chromosomal abnormalities, such as Turner (Fig. 29) and Down syndrome as the underlying cause. Other associated anomalies often found are fetal hydrops (Fig. 30), such as severe subcutaneous edema and pleural effusion.

Nonchromosomal syndromes can be caused by wide variety of agents, some of them are infective agent (Rubella syndrome., CMV syndrome, Parvo B19 $9^{59}$ and so on), teratogenic drug (Antiepileptic drugs, such as Valproate acid or Phenytoin, some vitamins: Vit A) or addictive substance: alcohol (Fetal Alcohol syndrome). ${ }^{58-63}$

On the basis of lethality, fetuses as well as neonates with congenital anomalies and syndromes can be divided into six groups: (1) those who have the potential for total recovery, (2) those with anomalies that would allow for a nearly normal life, (3) those with malformations requiring permanent supervision and/or medical care, (4) those with somatic rest defect and subnormal mental development, (5) those with serious somatic and mental damage, and (6) those with anomalies that are incompatible with life. ${ }^{52}$

After identifying anomalies and suspect a syndrome, there is next difficult thing. How to explain this to the parents? Naturally, parents are always expecting healthy child. Dealing with difficult situation of having malformed infant with incurable state is distressing and emotionally exhausting either the diagnosis is made preor postnatally. ${ }^{53,84}$

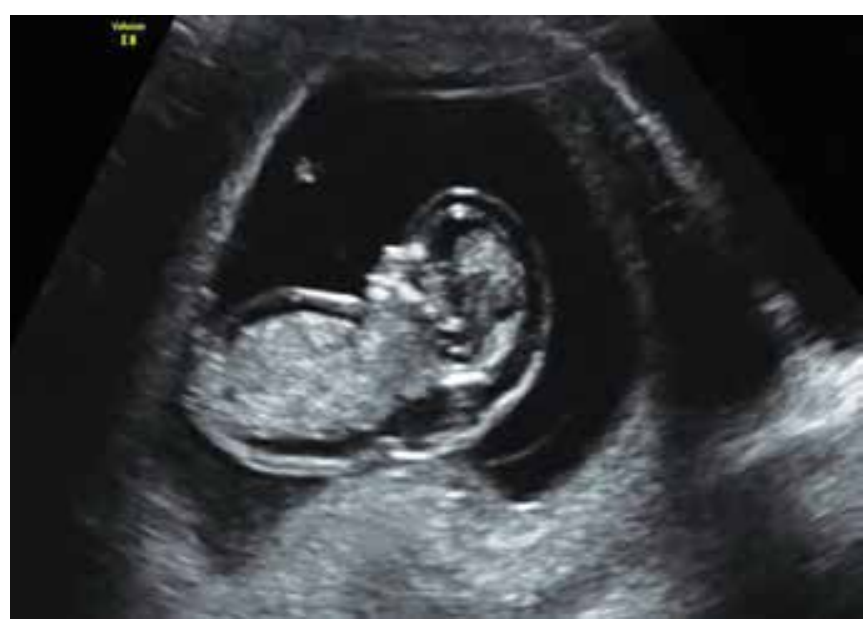

Fig. 30: Two-dimensional image of fetus with hydrops fetalis at 14 gestational weeks; Turner syndrome was confirmed (Courtesy: Dr RM Nieto)

Parents expect you to tell them what it means, the prognosis, recurrence risk, etc. Pediatric books, such as 'Smith's recognizable patterns of human malformations' ${ }^{14}$ five is very helpful in providing more detailed information about this.

It would be much easier for the infant's parents and healthcare provider to begin communication before birth. The ability to provide as clear information as possible is of great importance, to avoid confusion in parents, as well as other healthcare providers involved in the care. The aim of this communication between parents and healthcare provider is: to make parents understand the condition of the child, to put everything in the prospective: to inform them about the fetal prognosis, provide genetic counseling, inform them about the need for invasive testing, ${ }^{64}$ discuss the obstetric management plan, short- and long-term neonatal prognosis, neonatal management decisions, possibilities of the treatment, and finally to provide them with the information about the prognosis and outcome. ${ }^{67,68}$ As we mentioned before, as soon as it becomes feasible to identify anomalies at the prenatal stage, questions are raised also about what can and what should be done. ${ }^{67,68}$

Ethical issues involved. Modern medicine is facing the problem of the possibility to extend the life of many newborns with virtually lethal congenital malformations or other rare diseases, however, the possibility does not always justify the opportunity ${ }^{68}$ The potential of modern medicine to preserve life of the sickest newborns should not be overestimated, because it raises many ethical issues, which are still waiting to be solved. Why fetal surgery should be restricted to conditions that are lifethreatening to the fetus? The obvious answer is to protect mothers. Women should not have to undergo surgery unless it is absolutely necessary. ${ }^{68,69}$ 
If major malformations cause stillbirth or infant death in more than $50 \%$ of cases, they are considered lethal. If newborn infant with major congenital malformation cannot survive without medical intervention, than malformation is considered severe. ${ }^{70}$

\section{CONCLUSION}

From 2D, 3D, 4D to 5 th element in recent years it become increasingly difficult to keep up and stay on top of major research development. With a modern communication possibilities, almost in a instant manner, we find, assess and share scientific information easier and quicker than ever before.

Tremendous expansion of possibilities and available diagnostic tools (that can assist us in recognizing fetal anomalies and syndromes) in daily clinical practice, helps us to incorporate and process all the information, use the knowledge to form a unique conclusion in our brain which is the 5th element to complete the whole picture. In a such way, while working, we sharpen our senses, improve our efficiency, increase productivity and finally bring the quality of our work to another level.

We have to keep on improving the technology as well as our skills as it gives as opportunity to research and understand new things. As Vincent van Gogh once wrote... 'After all, there's nothing in the world as interesting as people, and one is never done with studying them. ${ }^{79}$

\section{REFERENCES}

1. Dorland's Illustrated Medical Dictionary online. Elsevier. Available at: www.dorlands.com/wsearch.jsp.

2. Lanna M, Rustico MA, Pintucci A, Spaccini L, Lalatta F, Nicolini U. Three-dimensional ultrasound and genetic syndromes. DSJUOG 2007 Jul-Sep;1(3):54-59.

3. Jakobsen LP, Knudsen MA, Lespinasse J, García Ayuso C, Ramos C, Fryns JP, Bugge M, Tommerup N. The genetic basis of the Pierre Robin Sequence. Cleft Palate Craniofac J 2006 Mar;43(2):155-159.

4. Jones, KL. Smith's Recognizable Patterns of Human Malformation. 5th ed. Philadelphia: Elsevier Saunders; 1997. Chapter1, Introduction including dysmorphology approach and classification. pp. 875 .

5. International Human Genome Sequencing Consortium. Initial sequencing and analysis of the human genome. Nature 2001 Feb;409:860-921.

6. International Human Genome Sequencing Consortium. Finishing the euchromatic sequence of the human genome. Nature 2004 Oct;431(7011):931-945.

7. Chaisson MJ, Huddleston J, Dennis MY, Sudmant PH, Malig M, Hormozdiari F, Antonacci F, Surti U, Sandstrom R, Boitano M, et al. Resolving the complexity of the human genome using single-molecule sequencing. Nature 2015 Jan;517(7536):608-611.

8. Nicolaides KH, Syngelaki A, Gil M, Atanasova V, Markova D. Validation of targeted sequencing of single-nucleotide polymorphisms for non-invasive prenatal detection of aneuploidy of chromosomes 13, 18, 21, X and Y. Prenat Diagn 2013 Jun;33(6):575-579.

9. Kurjak A, Miskovic B, Stanojevic M, Amiel-Tison C, Ahmed B, Azumendi G, Vasilj O, Andonotopo W, Turudic T, SalihagicKadic A. New scoring system for fetal neurobehavior assessed by three- and four-dimensional sonography. J Perinat Med 2008;36(1):73-81.

10. Kurjak A, Abo-Yaqoub S, Stanojevic M, Yigiter AB, Vasilj $O$, Lebit D, Shaddad AN, Ahmed B, Kavak ZN, Miskovic B, et al. The potential of $4 \mathrm{D}$ sonography in the assessment of fetal neurobehavior-multicentric study in high-risk pregnancies.J Perinat Med 2010;38(1):77-82.

11. Stanojevic M, Talic A, Miskovic B, Vasilj O, Shaddad AN, Ahmed B, Kadic AS, Predojevic M, Vladareanu R, AbuYaqoub DLS, et al. An Attempt to Standardize Kurjak's Antenatal Neurodevelopmental Test: Osaka Consensus Statement. DSJUOG 2012 Oct-Dec;5(4):317-329.

12. Benacerraf BR. Ultrasound of fetal Syndromes. 2nd ed. Churchill Livingstone, 2008. Chapter 1, Differential Diagnoses; Chapter 2, Syndromes. pp. 672.

13. Basel-Vanagaite L, Wolf L, Orin M, Larizza L, Gervasini C, Krantz ID, Deardoff MA. Recognition of the Cornelia de Lange Syndrome Phenotype with Facial Dysmorphology Novel Analysis. Clin Gene 2015 Dec 13.

14. Jones, KL. Smith's Recognizable Patterns of Human Malformations. 6th ed. Philadelphia, PA: Elsevier Saunders; 2006.

15. Stanojevic M, Antsaklis P, Kadic AS, Predojevic M, Vladareanu R, Vladareanu S, Neto RM. Is Kurjak Antenatal Neurodevelopmental Test Ready for Routine Clinical Application? Bucharest Consensus Statement. DSJUOG 2015 Jul-Sep;9(3):260-265.

16. Salomon LJ, Alfirevic Z, Bilardo CM, Chalouhi GE, Ghi T, Kagan KO, Lau TK, Papergeorghiou AT, Raine-Fenning NJ, Stirnemann J, et al. ISUOG Practice Guidelines: performance of first-trimester fetal ultrasound scan. Ultrasound Obstet Gynecol 2013 Jan;41(1):102-113.

17. ISUOG Education Committee [Internet]. Sonographic examination of the fetal central nervous system: guidelines for performing the 'basic examination' and the 'fetal neurosonogram'. Ultrasound Obstet Gynecol 2007 Jan;29(1):109-116.

18. Timor-Tritsch IE, Peisner DB, Raju S. Sonoembryology: an organ oriented approach using a high-frequency vaginal probe. J Clin Ultrasound 1990 May;18(4):286-289.

19. Pooh, RK. Neuroanatomy visualisation by $2 \mathrm{D}$ and 3D. In: Pooh RK, Kurjak A, editors. Fetal neurology. New Delhi: Jaypee Brothers Medical Publisers (P) Ltd.; 2009. p. 15-38.

20. Chaoui R, Nicolaides KH. From nuchal translucency to intracranial translucency: towards the early detection of spina bifida Ultrasound Obstet Gynecol 2010 Feb;35(2):133-138.

21. Nicolaides KH, Campbell S, Gabbe SG, Guidetti R. Ultrasound screening for spina bifida: cranial and cerebellar signs. Lancet 1986 Jul;2(8498):72-74.

22. Van den Hof MC, Nicolaides KH, Campbell J, Campbell S. Evaluation of the lemon and banana signs in one hundred and thirty fetuses with open spina bifida. Am J Obstet Gynecol $1990 \mathrm{Feb} ; 162(2): 322-327$.

23. Chaoui R, Benoit B, Mitkowska-Wozniak H, Heling KS, Nicolaides KH. Assessment of intracranial translucency (IT) in the detection of spina bifida at the 11-13-week scan. Ultrasound Obstet Gynecol 2009 Sep;34(3):249-252.

24. Ghi T, Pilu G, Falco P, Segata M, Carletti A, Cocchi G, Sanini D, Bonasoni P, Tani G, Rizzo N. Prenatal diagnosis of 
open and closed spina bifida. Ultrasound Obstet Gynecol 2006 Dec;28(7): 899-903.

25. Hyett, J.; Sonek J. Donald School Textbook of Ultrasound in Obstetrics and Gynecology. In: Kurjak A, Chervenak FA, editors. 3rd ed. New Delhi: Jaypee Medical Publishers (P) Ltd., 2011. Chapter 12, First-trimester ultrasound screening for fetal anomalies. pp. 174-188.

26. Plasencia W, Dagklis T, Pachoumi C, Kolitsi E, Nicolaides KH. Frontomaxillary facial angle at $11+0$ to $13+6$ weeks: effect of plane of acquisition. Ultrasound Obstet Gynecol 2007 Jun; 29(6):660-665.

27. Bonilla-Musoles F, Raga F, Bonilla F Jr, Machado LE, OsborneNG, Ruiz F, Castillo JC. Prune-belly syndrome versus posterior Urethral valve. DSJUOG 2010 Oct-Dec;4(4):405-417.

28. Paladini D, Morra T, Teodoro A, Lamberti A, Tremolaterra F, Martinelli P. Objective diagnosis of micrognathia in the fetus: the Jaw index. Obstet Gynecol 1999 Mar;93(3):382-386.

29. Pooh RK, Pooh K. Assessment of Fetal Central Nervous System. DSJUOG 2013 Oct-Dec;7(4):369-384.

30. Merz E, Welter C. Two-dimensional and three-dimensional ultrasound in the evaluation of normal and abnormal fetal anatomy in the second and third trimesters in a level III center. Ultraschall Med 2005 Feb;26(1):9-16.

31. Merz E, Abramowicz JS. Three-dimensional/four-dimensional ultrasound in prenatal diagnosis: is it time for routine use? Clin Obstet Gynecol 2012 Mar;55(1):336-351.

32. Benacerraf BR, Benson CB, Abuhamad AZ, et al. Three- and four-dimensional ultrasound in obstetrics and gynecology: proceedings of the American Institute of Ultrasound in Medicine Consensus Conference. J Ultrasound Med 2005 Dec; 24(12):1587-1597.

33. Maarse W, Berge SJ, Pistorius L, van Barneveld T, Kon M, Breugem C, Mink Van der Molen AB. Diagnostic accuracy of transabdominal ultrasound in detecting prenatal cleft lip and palate: a systematic review. Ultrasound Obstet Gynecol 2010 Apr;35(4):495-502.

34. Baumler M, Faure JM, Bigorre M, Baumler-Patris C, Boulot $P$, Demattei C, Captier G. Accuracy of prenatal three-dimensional ultrasound in the diagnosis of cleft hard palate when cleft lip is present. Ultrasound Obstet Gynecol 2011 Oct;38(4):440-444.

35. Evans KN, Sie KC, Hopper RA, Robin, Hing AV, Cunningham ML. Robin Sequence: From Diagnosis to Development of an Effective Management Plan. Pediatrics 2011 May;127(5):936-948.

36. Teoh M, Meagher S. First-trimester diagnosis of micrognathia as a presentation of Pierre Robin syndrome. Ultrasound Obstet Gynecol 2003 Jun;21(6):616-618.

37. Godbout A, Leclerc JE, Arteau-Gauthier I, Leclerc LD. Isolated Versus Pierre Robin Sequence Cleft Palates: Are They Different? Cleft Palate Craniofac J 2014 Jul;51(4):406-411.

38. Breugem CC, Courtemanche DJ. Robin Sequence: Clearing Nosologic Confusion. Cleft Palate Craniofac J 2010 Mar;47(2): 197-200.

39. Evans AK, Rahbar R, Rogers GF, Mulliken JB, Volk MS. Robin sequence: a retrospective review of 115 patients. Int J Pediatr Otorhinolaryngol 2006 Jun;70(6):973-980.

40. Pooh, RK.; Shiota, K.; Kurjak, A. Donald School Textbook of Ultrasound in Obstetrics and Gynecology. In: KurjakA, Chervenak FA, editors. 3rd ed. New Delhi: Jaypee Medical Publishers (P) Ltd., 2011. Chapter 33, Three-dimensional sonoembryology. pp. 540-547.
41. Tsai MY, Lan KC Ou CY, Chen JH, Chang SY, Hsu TY. Assessment of the facial features and chin development of fetuses with use of serial three-dimensional sonography and the mandibular size monogram in a Chinese population. Am J Obstet Gynecol 2004 Feb;190(2):541-546.

42. Cicero S, Curcio P, Rembouskos G, Sonek J, Nicolaides KH. Maxillary length at 11-14 weeks of gestation in fetuses with trisomy 21. Ultrasound Obstet Gynecol 2004 Jul;24(1):19-22.

43. Benacerraf, BR.; Bromley, B. Ultrasound of fetal syndromes. In: Benacerraf BR, editor. 2nd ed. Churchill Livingstone, 2008. Chapter 2, syndromes pp. 490-495. Chapter 3, Sonographic fetal findings with borderline significance-the grey zone in fetal diagnosis. pp 575-576.

44. Mangione R, Lacombre D, Carles D, Guyon F, Saura R, Horovitz J. Craniofacial dysmorphology and three-dimensional ultrasound: a prospective study on practicability for prenatal diagnosis. Prenat Diagn 2003 Oct;23(10):810-818.

45. Lager, D.; Neil, A. Practical Renal Pathology, A Diagnostic Approach: A Volume in the Pattern Recognition Series. Philadelphia: Elsevier Health Sciences; 2012 Sep 7. p. 27.

46. Chang LW, Chang FM, Chang $\mathrm{CH}, \mathrm{Yu} \mathrm{CH}$; Cheng YC, Chen HY. Prenatal diagnosis of fetal multicystic dysplastic kidney with two-dimensional and three-dimensional ultrasound. Ultrasound Med Biol 2002 Jul 1;28(7):853-858.

47. Sepulveda W, Illescas T, Adiego B, Martinez-Ten P. Prenatal Detection of Fetal Anomalies at the 11- to 13-week Scan-Part I: Brain, Face and Neck. DSJUOG 2013 Jan;7(4):359-368.

48. Bromley B, Nadel AS, Pauker S, Estroff JA, Benacerraf BR. Closure of the cerebellar vermis: Evaluation with second trimester US. Radiology 1994 Dec;193(3):761-763.

49. Hassold T, Merrill M, Adkins K, Freeman S, Sherman S. Recombination and maternal age-dependent nondisjunction: molecular studies of trisomY 16. Am J Hum Gene 1995 Oct;57(4):867-874.

50. Nicolaides KH, Snijders RJ, Gosden CM, Berry C, Campbell S. Ultrasonographically detectable markers of fetal chromosomal abnormalities. Lancet 1992 Sep 19;340(8821):704-707.

51. Gross SJ, Shulman LP, Tolley EA, Emerson DS, Felker RE, Simpson JL, Elias S. Isolated fetal choroid plexus cyst and trisomy 18: a review and meta-analysis. Am J Obstet Gynecol 1995 Jan;172(1 Pt 1):83-87.

52. Pinter AB. End-of-life decision before and after birth: changing ethical considerations. J Pediatr Surg 2008 Mar;43(3):430-436.

53. Saugstad OD. When newborn infants are bound to die. Acta Paediatr 2005 Nov;94(11):1535-1537.

54. Krakow D, Williams J 3rd, Poehl M, Rimoin DL, Platt LD. Use of three-dimensional ultrasound imaging in the diagnosis of prenatal-onset skeletal dysplasias. Ultrasound Obstet Gynecol 2003 May;21(5):467-472.

55. Timor-Tritsch IE, Bashiri A, Monteagudo A, Arslan AA. Qualified and trained sonographers in the US can perform early fetal anatomy scans between 11 and 14 weeks. Am Obstet Gynecol 2004 Oct;191(4):1247-1252.

56. Bricker L, Neilson JP, Dowswell T. Routine ultrasound in late pregnancy (after 24 weeks' gestation). Cochrane Database Syst Rev 2008 Oct;8(4):CD001451.

57. Schwärzler P, Senat MV, Holden D, Bernard P, Masroor T, Ville Y. Feasibility of the second-trimester fetal ultrasound examination in an unselected population at 18,20 or 22 weeks of pregnancy: a randomized trial. Ultrasound Obstet Gynecol 1999 Aug;14(2):92-97. 
58. Benoist G, Salomon LJ, Mohlo M, Suarez B, JocquemardF, Ville Y. Cytomegalovirus-related fetal brain lesions: comparison between targeted ultrasound examination and magnetic resonance imaging. Ultrasound Obstet Gynecol 2008 Dec;32(7):900-905.

59. Lamont RF, Sobel JD, Vaisbuch E, Kusanovic JP, Mazaki Tovi S, Kim SK, Uldbjerg N, Romero R. Parvovirus B19 infection in human pregnancy. BJOG 2011 Jan;118(2):175-186.

60. Merz E, Pashaj S. Current Role of 3D/4D sonography in obstetrics and gynecology. DSJUOG 2013 Jan;7(4):400-408.

61. Malinger G, Lev D, Zahalka N, Ben Aroia Z, Watemberg N, Kidron D, Sira LB, Hermansagie T. Fetal cytomegalovirus infection of the brain: the spectrum of sonographic findings. Am J Neuroradiol 2003 Jan;24(1):28-32.

62. Pretorius DH, Hayward I, Jones KL, Stamm E. Sonographic evaluation of pregnancies with maternal varicella infection. J Ultrasound Med 1992 Sep;11(9):459-463.

63. Puder KS, Treadwell MC, Gonik B. Ultrasound characteristics of in utero infection. Infect Dis Obstet Gynecol 1997;5(3): 262-270.

64. Murthy BR. Prenatal diagnosis of fetal syndromes. Indian J Radiol Imaging 2008 Nov;18(4):345-349.

65. Aagaard-Tillery KM, Malone FD, Nyberg DA, Porter TF, Cuckle HS, Fuchs K, Sullivan L, Com Stock CH, Saade GR, Eddleman K, et al. Role of second-trimester genetic sonography after Down syndrome screening. Obstet Gynecol 2009 Dec;114(6):1189-1196.

66. EUROCAT Working Group. 15 years of surveillance of congenital anomalies in Europe 1980-1994. Scientific Institute of Public Health, Louis Pasteur: Brussels; 1997. p. 251.

67. Chitty LS. Ultrasound screening for fetal abnormalities. Prenat Diagn 1995 Dec;15(13):1241-1257.

68. Pinter AB. End-of-life decision before and after birth: changing ethical considerations. J Pediatr Surg 2008 Mar;43(3):430-436.

69. Smajdor A. Ethical challenges in fetal surgery. Med Ethics $2011 \mathrm{Feb} ; 37(2): 88-91$.

70. Kumar P, Burton BK. Congenital Malformations: Evidencebased evaluation and management 1st ed. New York: McGraw-Hill Medical; 2008. pp. 408.

71. Stoll C, Dott B, Alembik Y, Roth MP. Evaluation of routine prenatal diagnosis by a registry of congenital anomalies. Prenat Diagn 1995 Sep;15(9):791-800.

72. Levi S. Routine ultrasound screening of congenital anomalies. An overview of the European experience. Ann NY Acad Sci 1998 Jun;847:173-180.

73. Garne E, Stoll C, Clementi M, Euroscan Group. Evaluation of prenatal diagnosis of congenital heart diseases by ultrasound: experience from 20 European registries. Ultrasound Obstet Gynecol 2001 May;17(5):386-391.

74. Stoll C, Garne E, Clementi E. Evaluation of prenatal diagnosis of associated congenital heart diseases by fetal ultasonographic examination in Europe. Prenat Diagn 2001 Apr;21(4):243-252.

75. Clementi M, Fenconi R, Bianchi F, Stoll C. Evaluation of Prenatal diagnosis of cleft lip with or without cleft palate and cleft palate by ultrasound: experience from 20 European registries. Euroscan study group. Prenat Diagn 2000 Nov;20(11):870-875.

76. Haeusler MC, Berghold A, Stoll C, Barisic I, Clementi M; Euroscan Study Group. Prenatal ultrasonographic detection of gastrointestinal obstruction: results from 18 European congenital anomaly registries. Prenat Diagn 2002 Jul;22(7): 616-623.

77. Barisic I, Clementi M, Hausler M, Gjergja R, Kern J, Stoll C. The Euroscan Study Group. Evaluation of prenatal ultrasound diagnosis of fetal abdominal wall defects by 19 European registries. Ultrasound Obstet Gynecol 2001 Oct;18(4): 309-316.

78. Stoll C, Clementi M. The Euroscan Study Group. Prenatal diagnosis of dysmorphic syndromes by routine fetal ultrasound examination across Europe. Ultrasound Obstet Gynecol 2003 Jun;21(6):543-551.

79. Van Gogh Museum, Amsterdam; inv. no. b497 V/1962, Br. 1990: 568 | CL: 457, From: Vincent van Gogh To: Theo van Gogh, Date: Antwerp, on or about Monday, 22 February 1886.

80. Pooh, RK; Kurjak, A. Donald School Atlas of Advanced Ultrasound in Obstetrics and Gynecology. 1st ed. New Delhi: Jaypee Brothers Medical Publishers (P) Ltd.; 2015 Sept. pp. 896.

81. Wladimiroff JW, Sachs ES, Reuss A, Stewart PA, Pijpers L, Niermeijer MF. Prenatal diagnosis of chromosome abnormalities in the presence of fetal structural defects. Am J Med Genet 1988 Feb;29(2):289-291.

82. Palmer CG, Miles JH, Howard-Peebles PN, Magenis RE, PatilS, Friedman JM. Fetal karyotype following ascertainment of fetal anomalies by ultrasound. Prenat Diagn 1987 Oct;7(8): 551-555.

83. Carvalho JS, Allan LD, Chaoui R, Copel JA, DeVore GR, Hecher K, Lee W, Munoz H, Paladini D, Tutschek B, et al. ISUOG Practice Guidelines (updated): sonographic screening examinationof the fetal heart. Ultrasound Obstet Gynecol 2013 Mar;41(3):348-359.

84. Walther FJ. Withholding treatment, withdrawing treatment, and palliative care in the neonatal intensive care unit. Early Hum Dev 2005 Dec;81(12):965-972.

85. Kurjak A, Azumendi G, Andonotopo W, Salihagic-Kadic A. Three- and four-dimensional ultrasonography for the structural and functional evaluation of the fetal face. Am J Obstet Gynecol 2007 Jan;196(1):16-28.

86. Azumendi G, Lausin I, Kurjak A, Pooh RK, Grant G. Ultrasonographic evaluation of fetal face by $3 \mathrm{D} / 4 \mathrm{D}$ sonography. DSJUOG, 2008 Oct-Dec;2(4):45-57. 